\title{
تقويم محتوى كتب التربية الدينية الإسلامية بالمرحلة الثانوية في ضوي قيم التسامح الديني وفقه الاختلاف
}

\section{بلال حمان السعيد الشال}

أونًا : مقدمة البحث :

الغاية التي رسمها لهم. ( عبــــ الله الأزدي،

. (TV. T. . E

وتهدف أيضًا إلى تتمية فكر الإنسان،

وتتظيم سلوكه، و عو اطفه، على أساس الدين

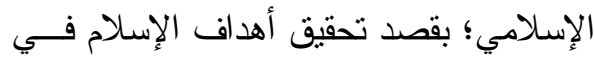

حياة الفرد، و الجماعة في كل مجالات الحياة.

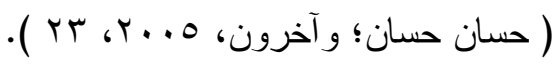

ومن أبرز أهداف التربية الدينية الاســلامية

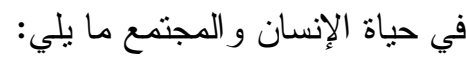

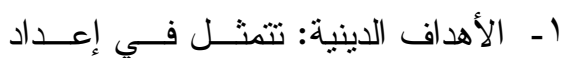

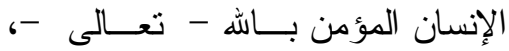

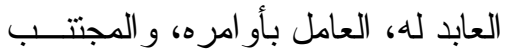

$$
\text { نو اهيه. }
$$

r- الأهداف الروحية: تتمنل في تــدعيم

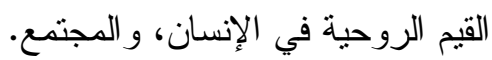

r- الأهداف الأخلاقية: تتمتل في إعـداد

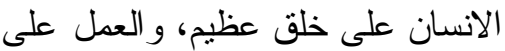

$$
\text { تدعيم القيم الأخلاقية. }
$$

عـ ـ الأهداف المعرفية: تتمنتل في تتميــة،

وترقية القوى العقلية، مثل: التفكيــر ،

$$
\text { و التذكر • }
$$

تسهم التربية الدينية الإسلامية في بناء

الإنسان الصالح؛ حيث إنها تحــدث تغييــرًا

إيجابيًا في سلوك الإنسان، وتكوينه النفسي،

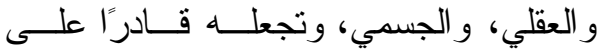

إظهار إمكاناته، وقدر اته، ومهار اته المختلفة؛

لتحسينها، و الرقي بها؛ ليصبح قادرًا علـى العى

التكيف في المجتمع الذي ينشأ فيه.

و التزبية الدينية الإسلامية - كر افد من

روافد التربية - تحث على التتمية المستمرة

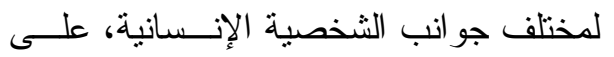

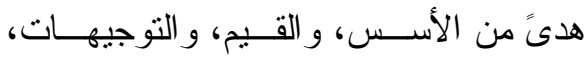

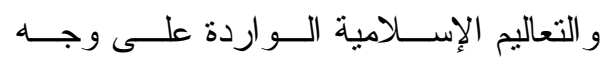

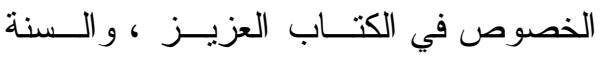

النبوية المطهرة؛ لتحقيق أهداف الإسلام فــي لــي

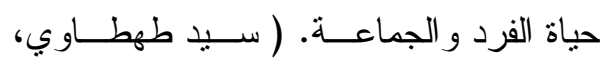

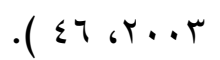

كما أنها عملية إنسانية تستهدف تتمية

الإنسان في مر احل حياته، بما يو افق أحكــام

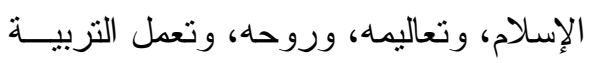

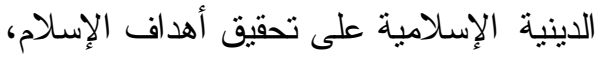

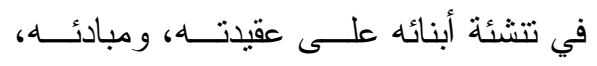

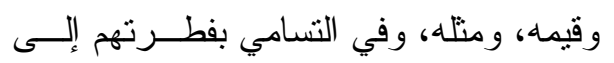


وهي التي تتظم سلوك الجماعة، وتوجهه إلى

0ـ الأهداف الاجتماعية: تتمنل في بنــاء

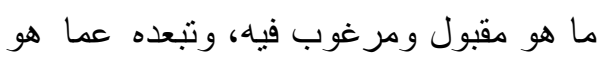

المجتمع على أسس التعاون، و التكافل

مرفوض ومنبوذ. ( فتحي يونس؛ و آخرون،

الاجتماعي، و العمل على تذعيم القــيم

$$
\text { . ( } 19 \text { ، r...V }
$$

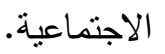

وهنالك مؤشر ات تـــل علــى القـيم،

T- الأهداف الدفاعية: تثمنل فـي الــدفاع

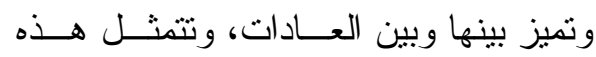

عن العقيدة الإسلامية، و إعداد الإنسان

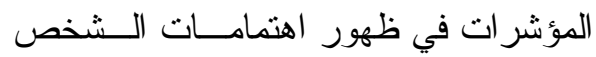

القوي.

بالقيمة، و اتجاهاته نحو ها، بالإضــافة إلـى لـى

V- الأهداف الجسمية: تتمثل في الطهارة

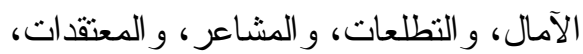

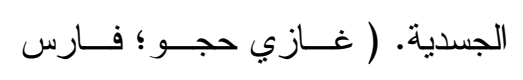

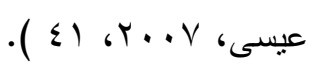

و الهموم، و المشكلات، التي ييرز من خلالها

جميعًا أن هذا الثخص يتبنى القيمة الفلانية،

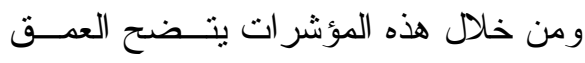

الثقافي للقيم، بالإضافة إلى المكونات الثلاثة:

المعرفي، و الوجداني، و الــسلوكي. ( إيمــان

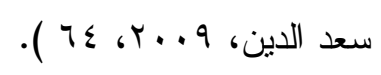

ومن أنواع القيم ما صــنفته فاطمـــة نــذر

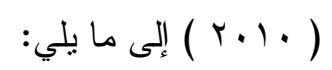

1- قيم روحية و عقدية: تتصل بحب الهه -

تعالى -، و الإيمان به، و الجهاد فــي

سبيله.

r- قيم خلقية: تتصل بالعدل، و التـسامح،

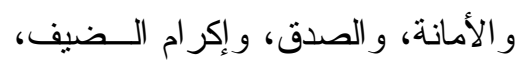

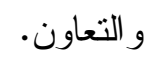

وتحتل القيم مكانةً مهمةً في التزبيــة لونة

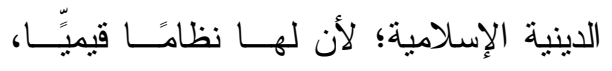
تغرسه في نفوس أبنائها منذ الصغر ، وتستمر

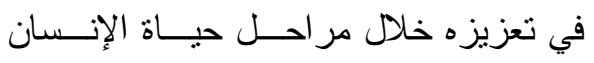
المختلفة؛ لأنها تقوم بدور أساس في تشكيل

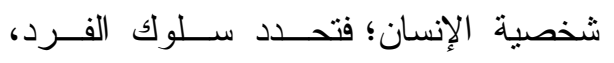
وتجعله قادرًا على التكيف مع الحياة، ومـــا فيها من مصاعب، وتحقق له رؤيةً و اضحةً

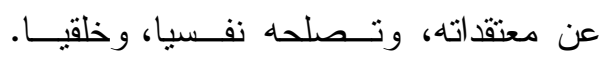

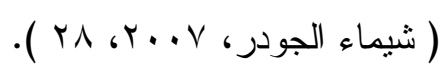

كما أنها مركز أساسي فـي توجيــهـ العملية التربوية؛ لما لها من أهمية كبيرة في حياة الفرد؛ حيث إنها ترتكز على المعتقدات

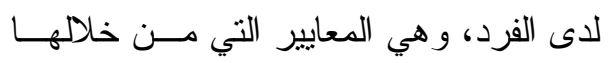
يقوم الفرد بحل مشكلاته مع الآخرين، وتسهر وهي

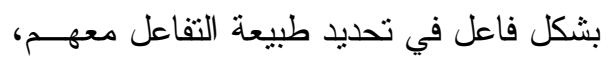


من خلالها ابتكار أساليب تقويمية ملائمــة؛

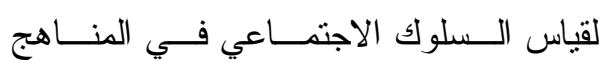

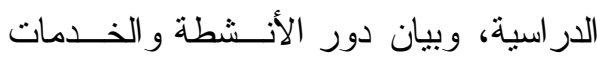

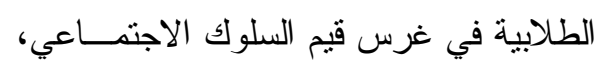
و الصحي.

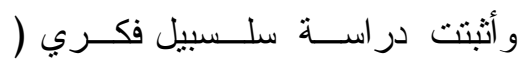

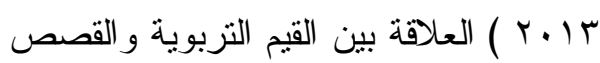

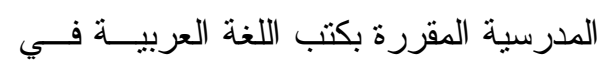
الحلقة الأولى من التعليم الأساسي، و وتوصلت بكتئ

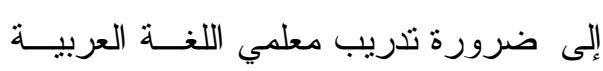
ومعلماتها على استز اتيجيات غـــرس القــيم وتتميتها في مر احل التعليم المختلفة - لاسيما في المرحلة الابتدائية -؛ ذلك لأن حشد القيم

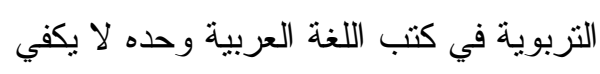

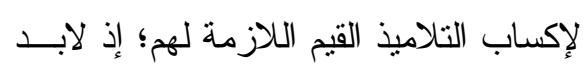

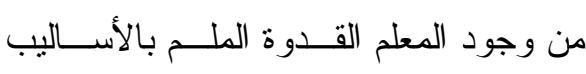
و الوسائل، التي يسنطيع من خلالها تحويـلـل

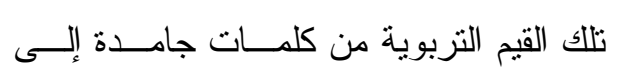
مو اقف تربوية متحركة.

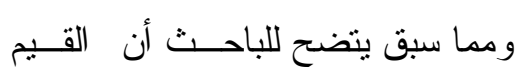

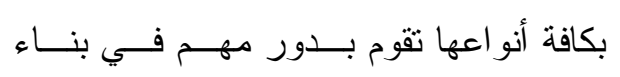

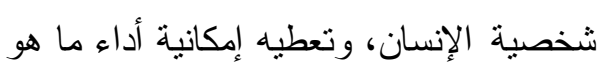
مطلوب منه؛ لذلك فإنها تجعله أقدر و أصــبر

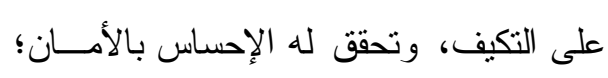
لأنها تقويه على مو اجهة ضعف النفس. كما أن القيم تــدفع الفــرد لتحـسين

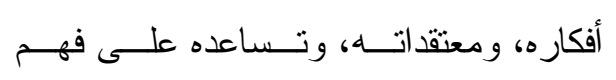

r- قيم عقلية: تتصل بالمعرفة، وطــرق

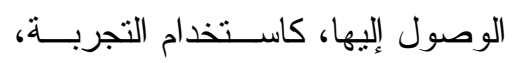
و التفكير الناقد. ع - قيم وجدانية و انفعالية: تتصل بالحب، و الكره، وضبط النفس عند الغضب.

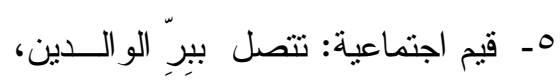

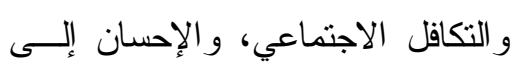

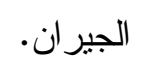
T- قيم مادية: تتصل بالعناصر الماديــة،

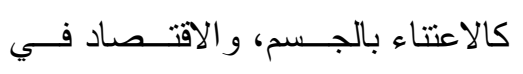
الإنفاق.

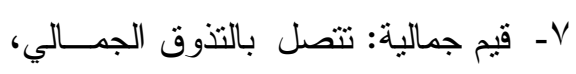

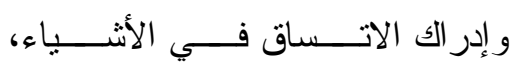

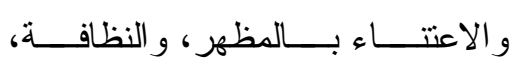

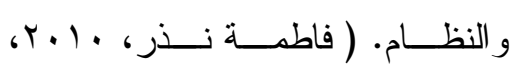
.$(1 \mathrm{VV}$ وقد تتاولت بعضُ الدر اساتِ و البحوث.

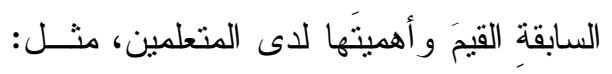
در استي ( السعيدي محمود، V. . . Y؟ سلسبيل

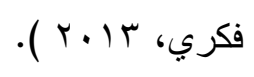
فقد كثفت در اسة الــسعيدي محمــود عن و اقع تدريس الموضــــ ( . . V )

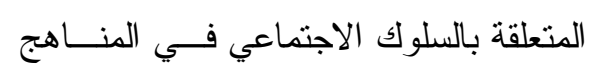

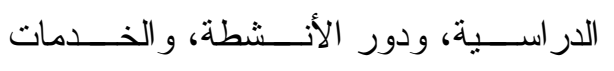

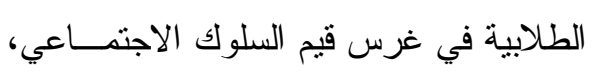

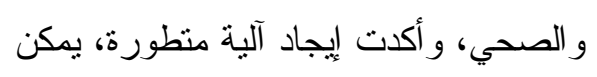




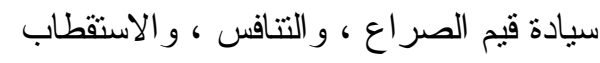
الحاد ، و الإقصاء .

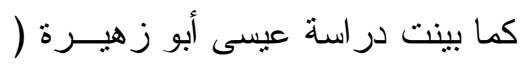

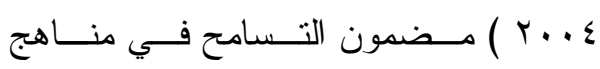
فلسطين الدر اسية من خــلال الإجابــة عـن كن

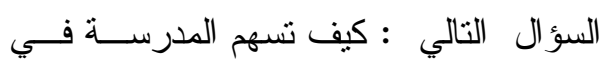

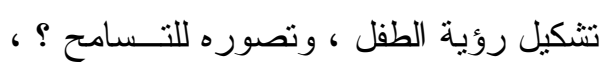

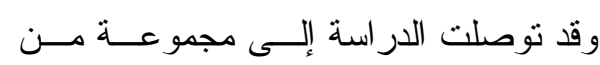

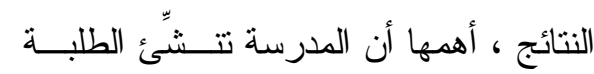

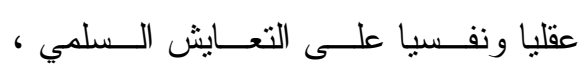
و التسامح مع الأديان الآخرين ، و احتر ام دور

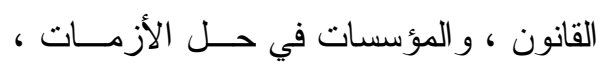

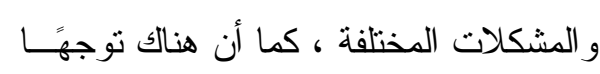
فلسطينيّا لتعزيز قيم التسامح ، و المساو اة في

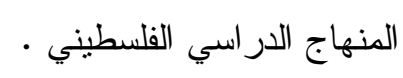

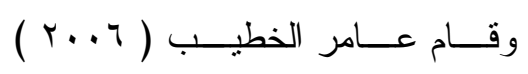

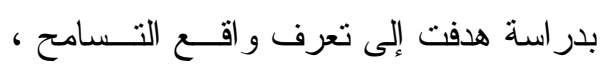

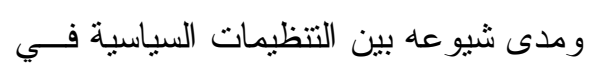
المجتمع الفلسطيني ، ودور التزبية في تعزيز قيم وثقافة التسامح فيه ، كما هدفت إلى تقديم توصيات ، ومقترحات يؤمل مـن خلالهـ فيـا الإسهام في بناء مجتمع فلسطيني الغد ، أكثر

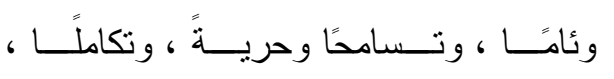

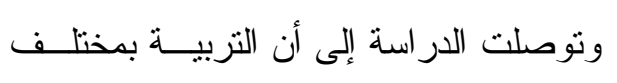

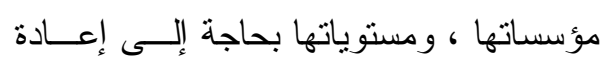

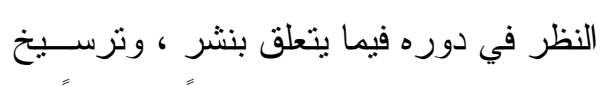

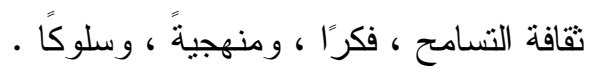

الآخرين من حوله، وتوسع إطاره المرجعي

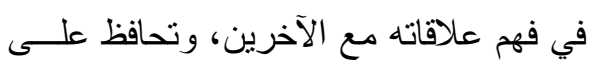

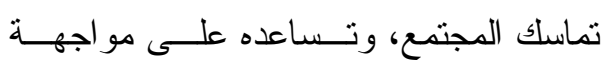

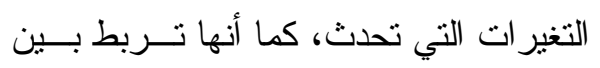
أجز اء النقافة في المجتمع؛ لأنها تعطي النظم

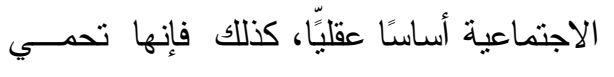

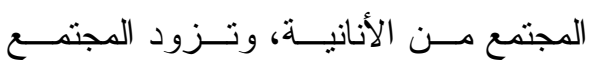

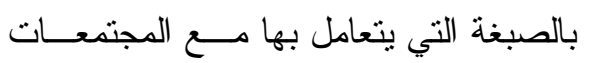

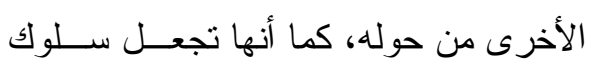
الجماعة عملًا تبتغي به وجه الله - تعالى و التسامح الديني كقيمة برتبط بكافــة

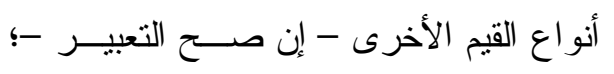

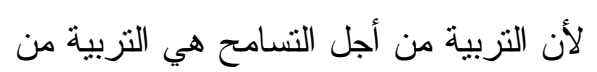
أجل تكوين القيم.

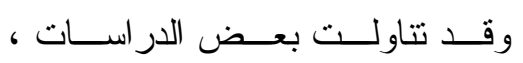
و البحوث السابقة قيم التسامح الديني ، و أهمية

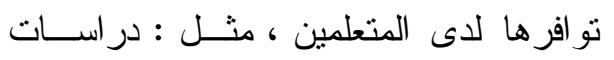

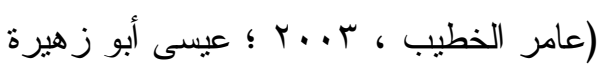

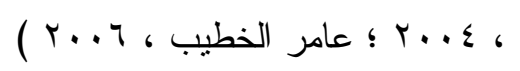

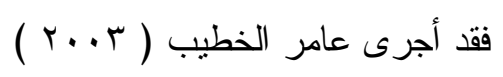
در اسة نظرية هدفت إلى تعرف و اقع التسامح

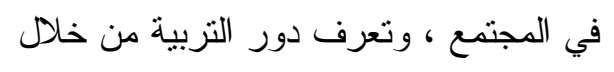

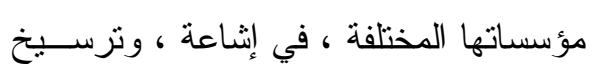

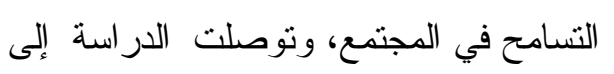

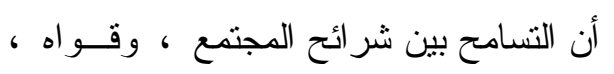

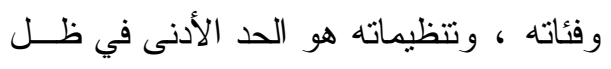




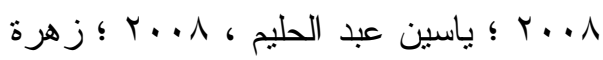

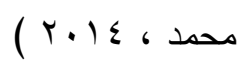

فقد بينــت دراســة بنــدر الــسويلم

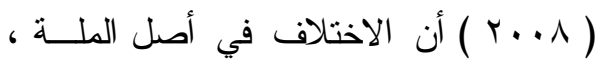

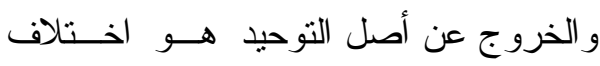

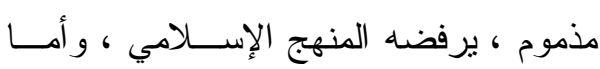

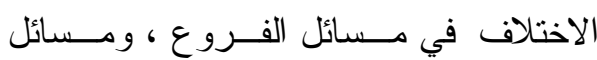

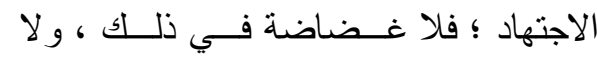

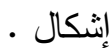

وأوضحت دراسة ياسين عبد الحـــيم

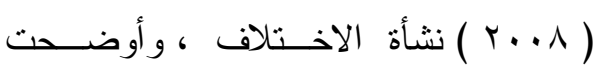

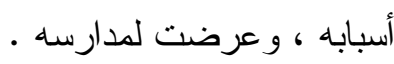

كما كثنت دراســة زهــرة محمــد

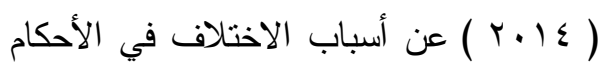
الثرعية ، وعرضت بعض النطبيقات فـي بابي الطهارة ، و الصـلاة من كتــاب بدايــة

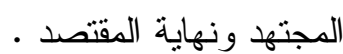

و التربية الدينيــة الإســلامية كمــادة در اسية - وخاصة بالمرحلة الثانوية - قادرة

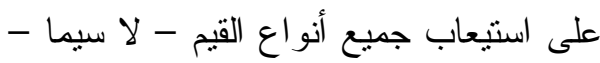

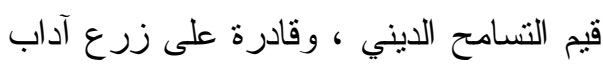
الاختلاف المحمود في نفوس الطلاب. هذا؛ وقد تتاولت بعض الدر اســات ،

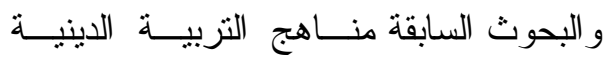
الإسلامية ، ومقرر اتها ، مثنـل : در اســات

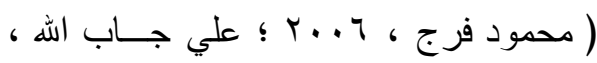

مدا سبق يتضح للباحث أن التـسامح

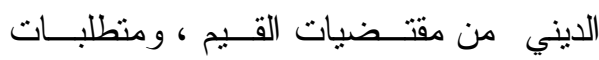

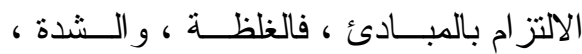
و العنف في العلاقات الاجتماعية ، و الإنسانية

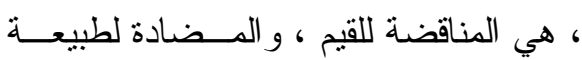

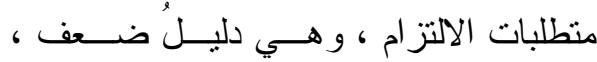

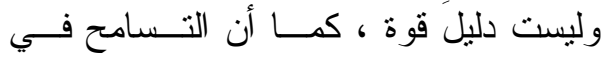

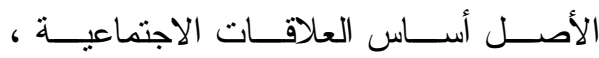

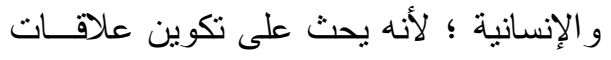
قائمة على المحبة ، و المــودة ، و التــآلف ؛ ؛ ؛

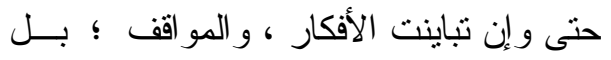

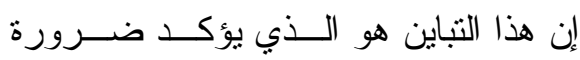
الالتز ام بهذه القيم ، وتلك المبادئ .

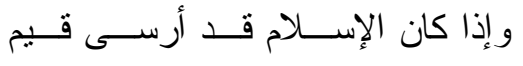

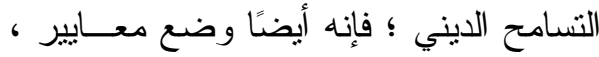
وقو اعد ، وأسسًا لفقه الاختلاف . لانها

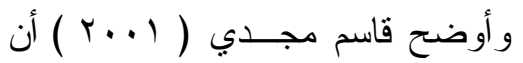
الاختلاف ضرورة ، وطبيعة بشرية ، منه ما ما ماند هو مذموم ، ومنه ما هو جائز ، وللاختلاف لانه

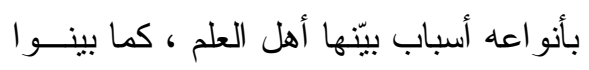
آدابه ، وينبغي على المسلمين - لاسيما طلبة

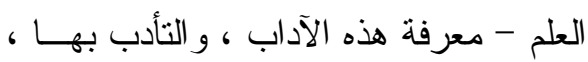

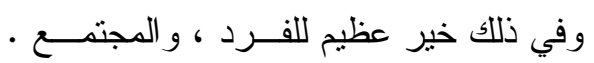

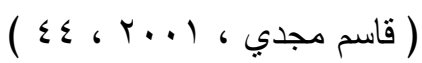

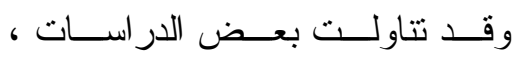

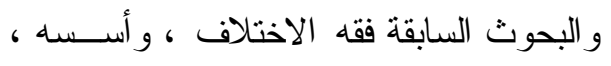

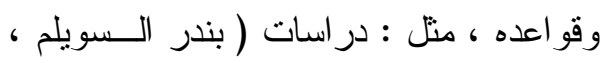


ثانيًا: الإحساس بمشكلة البحث :

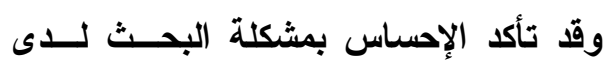

الباحث من خلا المصادر التالية :

أوثًا : الدراسات ، والبحوث السابقة ، وذلك

$$
\text { كما يلي : الإل : }
$$

ا - في مجــال منـــاهج التربيــة الدينيــة

الإسلامية :

، أكدت مجموعــة مــن الدراســـات

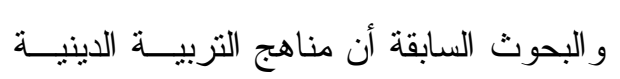

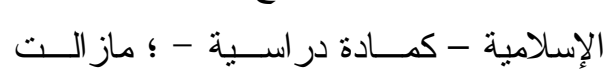

نواجه صعوبات عدة في مدارسنا ، ومنها :

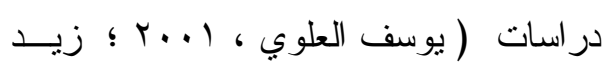

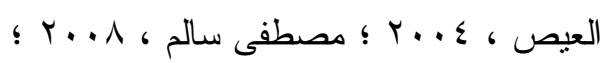

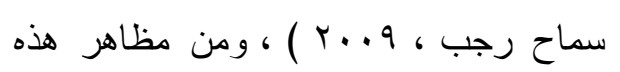

الصعوبات ما يلي : رج ،

• صعوبة تطبيق أهداف التربيـــة الدينيـــة

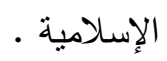

• كثرة تفريع مادة التربية الدينية الإسلامية

• عدم مناسبتها لاحتياجات المتعلمين •

• إبراز القـيم بــصورة غيــر كافيــة ،

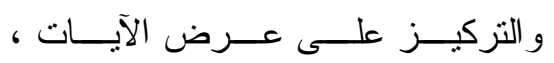

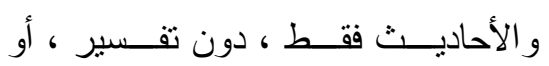

$$
\text { شرح. }
$$

r- في مجال قيم التسامح الديني :

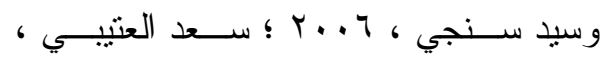

$(r \cdot . q$

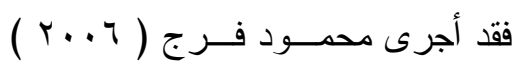

در اسة هدفت إلى تقــديم تــصور مقتــرح

لتضمين القيم البيئية في مناهج التزبية الدينية

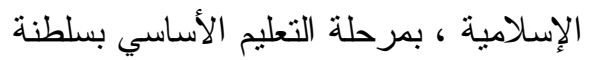

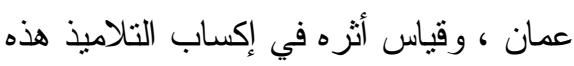
القيم -

وقام علي جاب الله ، وســيد ســنجي

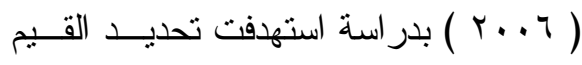

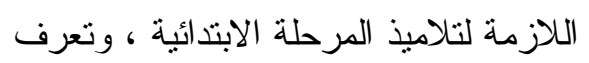

مدى تضمنها بكل من منهج التربية الدينيــة

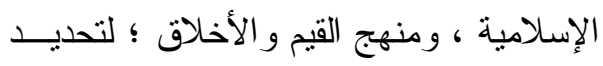
إلى أي مدى يسهم كل منهما بصورة أكبــر

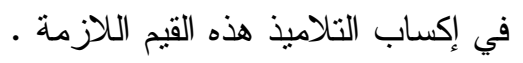

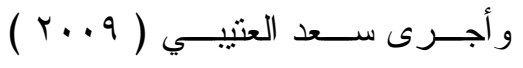

در اسة هدفت إلـى تعــرف مــدى احتــو اء

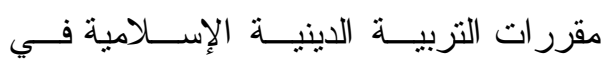

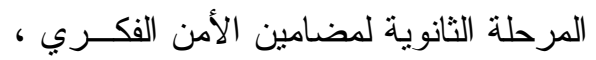

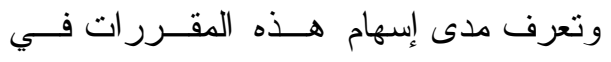

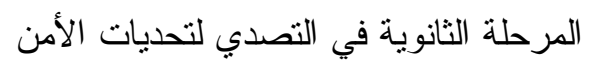
الفكري المعاصرة ، وتعرف مدى ممارســة

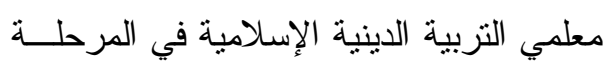

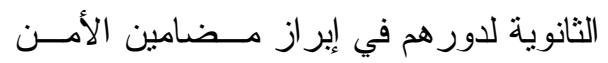

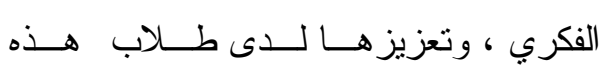
المرحلة. 
• فقدان محتوى كتــب التربيــة الدينيـــة الإسلامية التر ابط ، و التوازن ، و التكامل بين القيم

\section{ب- في مجال فقه الاختلاف :}

أثبتت بعض الدر اســـات ، و البحــوث

السابقة في مجال مناهج تعليم التزبية الدينيــة الإسـلامية أن الواقع الحالي لكتــبـ التربيــة الدينية الإسلامية في مدارسنا يؤكد أن هناك

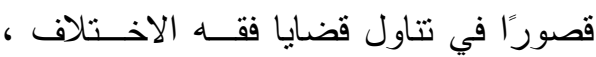
وخاصة بالمرحلة الثانويــة ؛ حيـــث إنهـــا تعرض لها بطريقة غير مباثرة ، وتقتــر

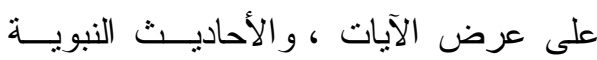
الشريفة دون تحليل ، أو تطبيق • ( مصطفى

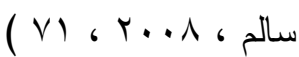

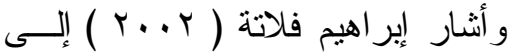
أن قضنايا فقه الاختلاف لم تأخذ الحيز الـذذي تستحقه في كتب التربية الدينية الإســالامية ، و إنما عرضت بطريقة مختصرة .

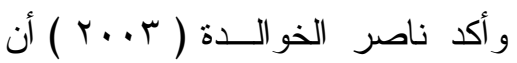
مناهج التربية الدينية الإسلامية لم تتمكن من تزويد الثباب بالتــصور المتكامــل للحيـــاة الإسـلامية المبنية علــى العلـــم ، و العمــلـل ،

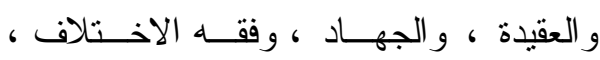

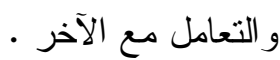
وأوضحت فوزية الـسعيد ( ؟ . . ) أن من أبرز ما يعيب مناهج التربية الدينيــة
بالر غم من تأكيد بعض الدر اســات

و البحوث أهمية تضمين كتب التربية الدينيــة الإسلامية لقيم التسامح الديني ، وفاعليتها في تحقيق أهداف مناهج التربية الدينية الإسلامية ، ومنها در اسات : ( بكر المو اجدة ، . 1 . ب

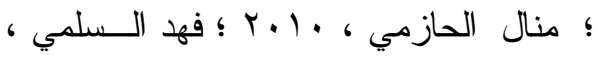
• • ( ) ) ، إلا أنه قد أسفرت نتائج كثير من الدراسات ، و البحوث التزبوية الميدانية فــي مجال القيم عامة ، وقـيم التـسامح الــديني خاصة ، أن هنالك قصورًا في تضمين كتــب ، التربية الدينية الإسلامية قيم التسامح الديني و أنها لا تشير بالثكل المرضي ، و الكيفيـة الو اجبة ؛ لذلك فإنهـــا تحـــول دون تحقبــق الأهداف المرجوة من غرس تلك القيم ، منل : دراسات ( محمد الثمري ، ^ ... ؛ سعد

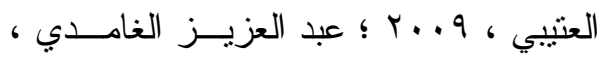

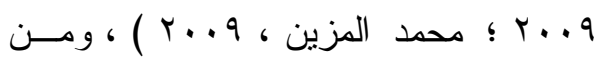
مظاهر ذلك القصور ما يلي : • تضمين ثقافة التسامح الــديني بــصورة غير كافية بمقــرر ات التربيــة الدينيـــة

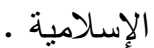
• تركيز مناهج التربية الدينية الإســلامية على التذكر ، و الحفظ فقط . • عدم مر اعــاة كت ـب التربيــة الدينيــة الإسلامية لطبيعة القيم ، و عدم عرضها بصورة عملية . 
أيضًا من خلا القيام بدراسة استطلاعية في محاولة لتعرف و اقع تضمين قـيم الــسامح الديني وفقه الاختلاف في كتب التربية الدينية الإسلامية بالمرحلة الثانوية ، من خلال إعداد استبانة وجهت إلى عشرين معلمًا من معلمي

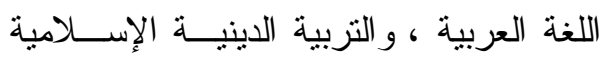

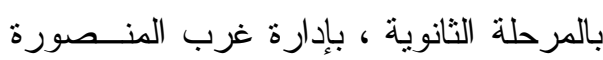
التعليمية ، وذلك فــي بدايــة شــــر ينـاير .$r \cdot 11$

وقد وجه الباحــث إلـــهم الــسؤ الين التاليين : هل تتو افر هذه البنود فــي كتـبـ التربية الدينية الإسلامية بالمرحلة الثانويــة ؟ و هل هناك موضو عات أخرى ترون إضافتها لنتلك الكتب ؟ ، وتم التوصــل إلــى النتــائج

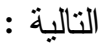

الإسلامية هو عدم تقبل الطلاب لها ؛ وذلــــك

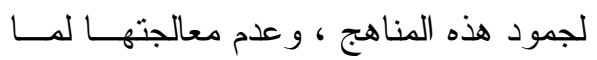

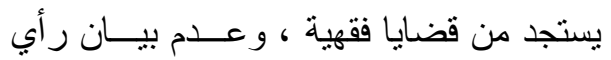
الثريعة الإسلامية فيها ؛ وذلك منل : الاتفاق

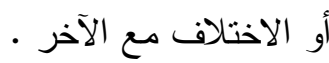

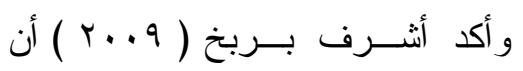
مناهج التزبية الدينية الإســلامية ينبغــي أن يكون لها دور كبير في تقهم طبيعة الوضــع المحيط بالطالب ؛ بحيث تتمكن من احتــو اء الاتجاهات الخلقية ، التي تتعارض مع مبادئ

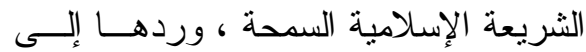
نصابها الطبيعـي فـي سلـــلة الأخــلاق الإسلامية .

ثانيًا : الارسة الاستة الاستطلاعية : بالإضـافة إلى الأســـباب ، و الــدو اعي السابقة ، فان الباحث قد استشعر هذه المشكلة 
جدول ( )

نتائج الاراسة الاستطلاعية

\begin{tabular}{|c|c|c|c|c|}
\hline \multirow{2}{*}{ 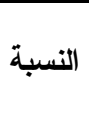 } & \multicolumn{2}{|c|}{ العدد العد } & \multirow{2}{*}{ 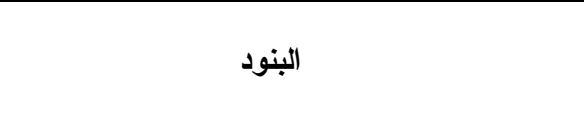 } & \multirow{2}{*}{ p } \\
\hline & غير متو افر & متو افر & & \\
\hline$\% ч$ & ir & & نبذ العنف و التطرف الديني . & 1 \\
\hline$\%$ & ir & & ترسيخ مبادئ الأخوة في الدين . & $r$ \\
\hline$\% \uparrow$ & ir & & احترام القيم الإيمانية الصحيحة عند الآخرين . & $r$ \\
\hline$\% 4$ & ir & & تقدير القيم الاجتماعية الإيجابية السائدة . & $\varepsilon$ \\
\hline$\% 4$ & ir & & ترسيخ المشاركة المجتمعية . & 0 \\
\hline$\% \uparrow$ & ir & & تتمية قيم التكافل الاجتماعي . & 9 \\
\hline$\% r$. & & 7 & حماية الأفكار من مظاهر النتويه الثقافي & $\mathrm{v}$ \\
\hline$\% r$. & & 7 & تتمية القدرة على التفكير العلمي . & $\wedge$ \\
\hline$\% r$. & & 9 & تعزيز قيم الأمانة العلمية . & 9 \\
\hline$\% r$. & & 7 & تتمية الثعور بالمسئولية الوطنية & 1. \\
\hline$\%$ r. & & $\varepsilon$ & تعزيز قيم النعايش السلمي . & 11 \\
\hline$\%$ r. & & $\varepsilon$ & تتمية قيم الحرية المنضبطة . & ir \\
\hline$\% r$. & & $\varepsilon$ & حماية الأفكار من عمليات التبعية العمياء . & ir \\
\hline$\% 1$. & & r & المحافظة على التو ازن بين التتافس و التعاون ـ & $1 \varepsilon$ \\
\hline$\% 1$. & & r & الاحتر ام للر أي الآخر ، ووجهات النظر الأخرى . & 10 \\
\hline$\% 1$. & & $r$ & القبول للفرد وللآخر & 17 \\
\hline$\% 1$. & & $r$ & تجنب التعصب للفكرة أو الر أي & iv \\
\hline
\end{tabular}

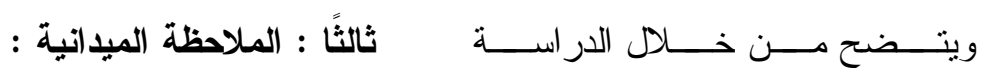

لاحظ الباحث من خـــالد الملاحظـــة

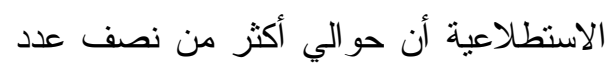

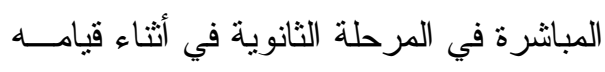

المعلمين لا يرون تضمين بنود الاستبانة في لإني

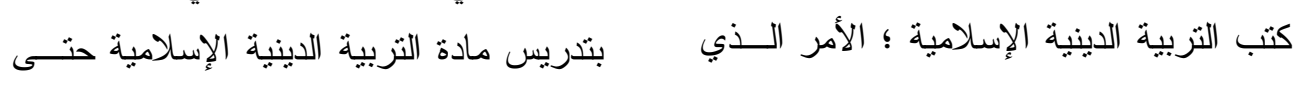

يدعو إلى القيام بدر اسة حالية ؛ لبناء تصور الآن ، وجود قصور في تضمين كتب التربية

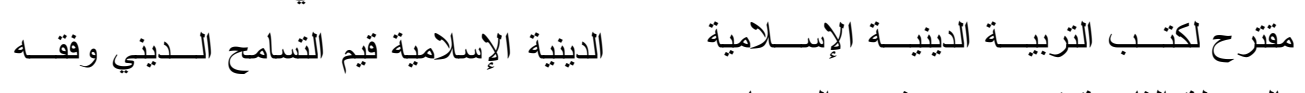

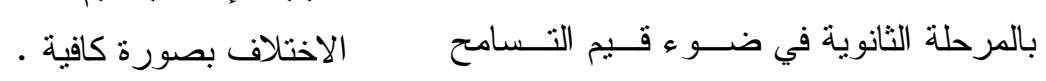

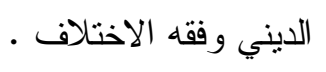


• ر رابعًا : أن كتب التربية الدينية الإسلامية

بالمرحلة الثانوية مجال خصب لتنميــة

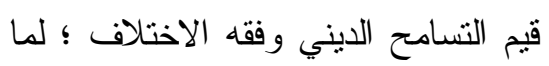

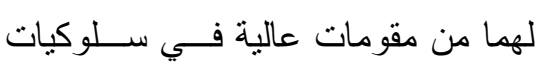

طلاب هذه المرحلة العمرية الحرجة .

خامسًا : لم تشر در اسات علمية - فــي

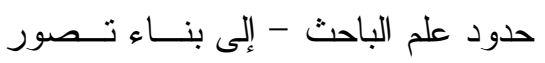

مقترح لكتب التزبية الدينية الإســلامية بالمرحلة الثانوية في ضوء قيتر التئ لنسامح

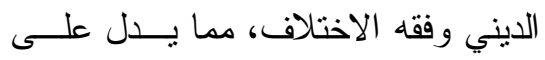

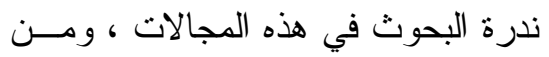

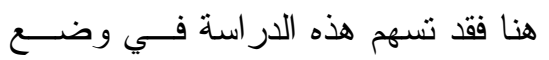

تصور مقترح لكتــب التربيـــة الدينيــة الإسلامية بالمرحلة الثانوية في ضـــو هو قيم التسامح الديني وفقه الاختلاف ؛ مما استوجب القيام بهذه الدراسة .

ثالثًا: تحديد مشكلة البحث :

تتمثل مشكلة البحث الحالي في حاجة

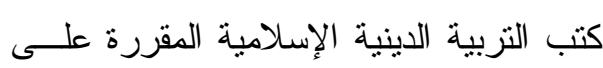

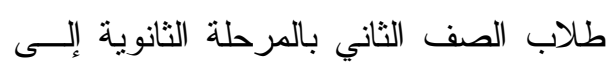

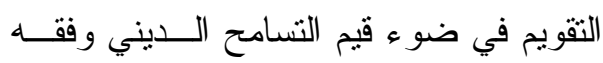
الاختلاف ، مما تطلب إيجاد حلــول لهـــهـ فئه

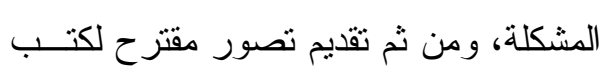

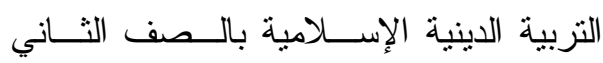

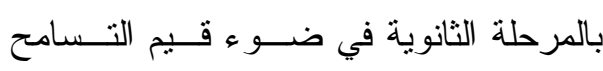

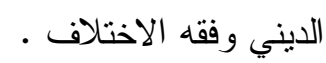

وبعد استعر اض مـــا أمكــن اللباحــث

الحصول عليه - في حدود إمكاناته - مسن لئن

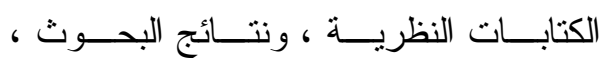

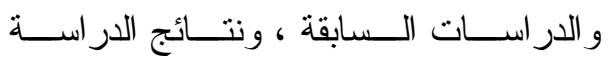

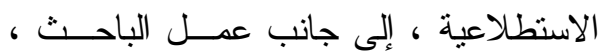

وخبرته في مجال تدريس مادة التربية الدينية

الإسلامية ، يمكن عرض مشكلة البحث فـي لئي النقاط النظرية التالية :

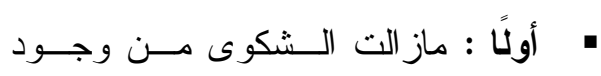
قصور في تضمين كتب الثربية الدينيــة الإسلامية بالمرحلة الثانوية القيم الدينية ، ولعل ذللك برجع إلى أســباب كثيـــرة منها : عدم الوعي بأهداف تعليم التربية

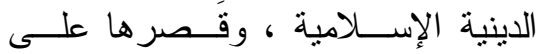
الجانب التحصيلي للموضوعات الدينية (لإنية السور ، والآيات القرءانية ، والأحاديث

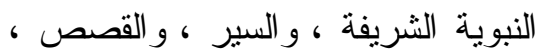

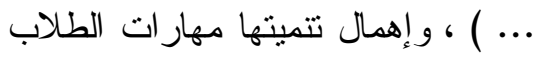

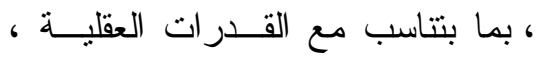
و المعرفية لهؤ لاء الطــلاب ، ، وإغفــال تتمية القيم اللازمة لهم لهولاه

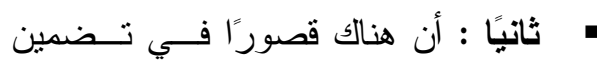

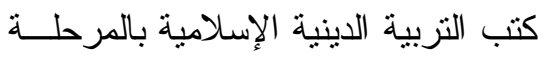
الثنانوية قيم التسامح الديني .

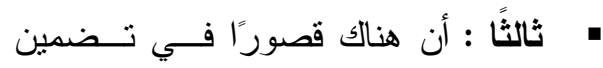

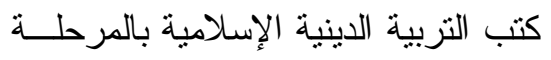
الثانوية معايير فقه الاختلاف . 


$$
\begin{aligned}
& \text { ضوء قــيم التــسامح الــديني وفقـــه } \\
& \text { الاختلاف ؟ }
\end{aligned}
$$

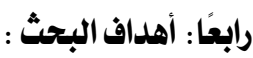

$$
\begin{aligned}
& \text { يهذف البحث الحالي إلى ما يلي : } \\
& 1 \text { - تحديد قيم التسامح الديني ، ومعايير فقه }
\end{aligned}
$$

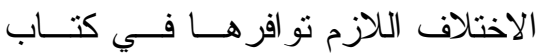

$$
\begin{aligned}
& \text { التزبية الدينية الإسلامية المقــرر علـى العى }
\end{aligned}
$$

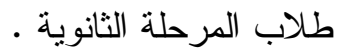

$$
\begin{aligned}
& \text { r - تحديد مدى نو افر قيم التسامح الــديني } \\
& \text { ومعايير فقه الاختلاف في كتاب التربية }
\end{aligned}
$$

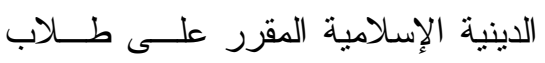

$$
\begin{aligned}
& \text { المرحلة الثانوية . النداديه } \\
& \text { r- تقديم تصور مقترح لكتب التزبية الدينية }
\end{aligned}
$$

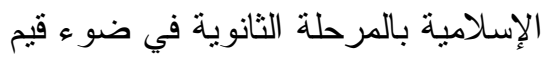

$$
\begin{aligned}
& \text { التسامح الديني وفقه الاختلاف بالاسله } \\
& \text { خامساً : أهمية البحث : } \\
& \text { أ- أهمية البحث بالنـسبة لمجــال منــاهج }
\end{aligned}
$$

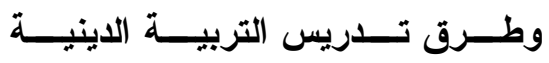

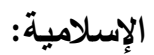

$$
\begin{aligned}
& \text { 1- إبر از نقاط القوة ونقــاط الــضعف فــي } \\
& \text { كتاب التربية الدينية الإسلامية المقــرر } \\
& \text { على طلاب المرحلة الثانوية . } \\
& \text { r- فتح المجال لتقويم كتب التربية الدينيـــة } \\
& \text { الإسلامية في ضوء قيم التسامح الــديني }
\end{aligned}
$$

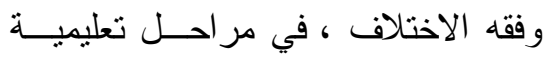

$$
\begin{aligned}
& \text { أخرى ، وتقديم تصور ات مقترحة لكتب } \\
& \text { ويمكن تحديد هذه المشكلة فــي التـساؤل } \\
& \text { الرئيس التالي : } \\
& \text { كيف يمكن تقديم تصور مقترح لكتب } \\
& \text { التربية الدينية الإسلامية بالمرحلة الثانوية في } \\
& \text { ضوء قيم التسامح الديني وفقه الاختلاف ؟ } \\
& \text { وتتبثق عن هذا التساؤل الرئيس الأســئلة } \\
& \text { الفرعية التالية : } \\
& \text { 1- ما قيم التسامح الديني اللازم تو افرهـــا }
\end{aligned}
$$

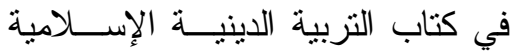

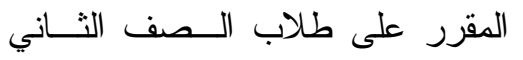

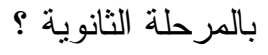

$$
\begin{aligned}
& \text { ץ- ما معــايير فقــهـه الاخــتلاف الـــلازم } \\
& \text { تو افرها في كتــاب التربيــــة الدينيـــة }
\end{aligned}
$$

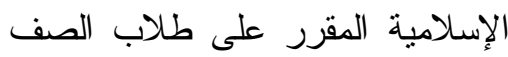

$$
\begin{aligned}
& \text { الثاني بالمرحلة الثانوية ؟ الإسله } \\
& \text { r- ما مدى نو افر قيم التسامح الديني فــي } \\
& \text { كتاب التزبية الدينية الإسلامية المقرر } \\
& \text { على طلاب الصف التــاني المرحلـــة } \\
& \text { الثانوية ؟ }
\end{aligned}
$$

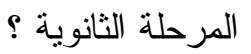


r- تتمية قـيم التـسامح الــديني ، وفقــــ

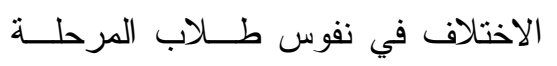

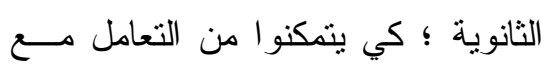

$$
\text { المخالف ، و الحوار معه . }
$$

ب- الإسهام في بناء المتعلم بنــاءً إســلاميًًا سليمًا ، من خلال بث قيم التسامح الديني

$$
\text { ، وفقه الاختلاف في نفسه . }
$$

د أهمية البحث بالنسبة للباحثين :

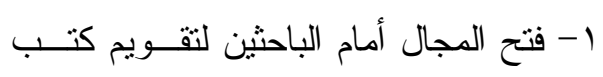

التربية الدينية الإسلامية ، ونطوير ها في لئين

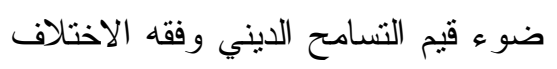

، وتقديم تصور ات مقترحة لكتب التربية

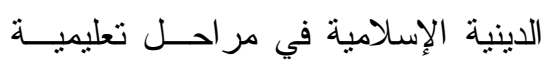

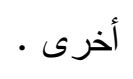

r- لفت نظر الباحثين إلى ضرورة الإفــادة

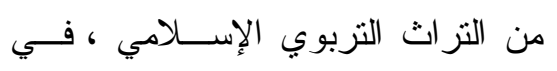

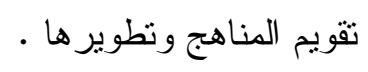

سادسًا : أدوات البحث : الهت

اعتمد البحث الحالي على الأدوات التالية :

1 - قائمة بقيم التسامح الديني اللازم تو افرها

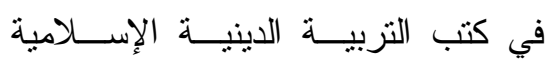

بالمرحلة الثانوية ـ ( إعداد الباحث )

r - قائمة بمعايير فقــهـ الاخــتلاف الــلازم

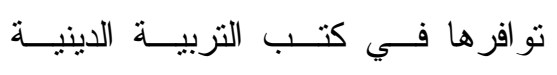

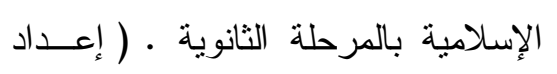

(الباحث )
التربية الدينيــة الإســلامية فــي هـــه المر احل .

r- تقديم تصور مقترح لكتب التربية الدينية

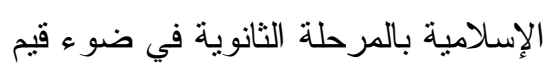

$$
\text { التسامح الديني وفقه الاختلاف . }
$$

ب- أهمية البحث بالنسبة لمعلمي التربيـة

\section{الاينية الإسلامية : المبه البال}

1- تقديم نموذج لأداة لتقويم كتاب التزبيــة لإسيـة

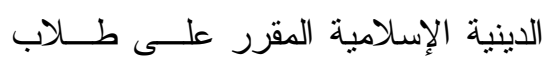

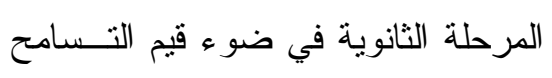
الديني ومعايير فقه الاختلاف .

r- الإسهام فـي تحسسين مـستوى الأداء

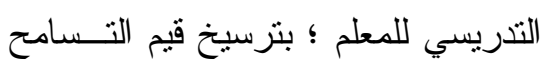

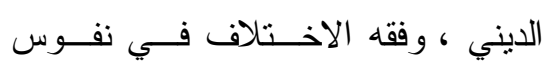

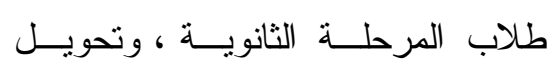

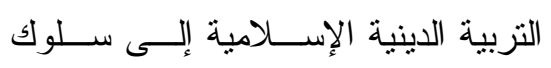

$$
\text { عملي على أرض الواقع • }
$$

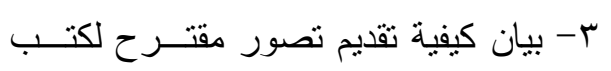

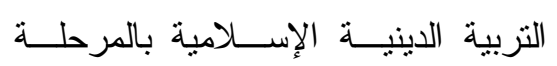

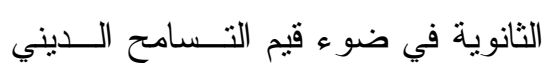

وفقه الاختلاف .

ج- أهمية البحث بالنسبة للطلاب :

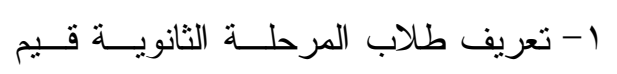

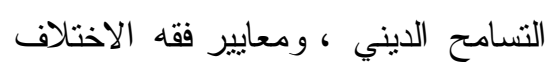

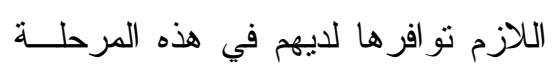

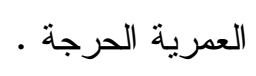


ويستخدم المنهج الوصفي في هـــا

$$
\text { البحث ؛ وذلك سعيًا إلى : }
$$

- تعرف المتو افر من قيم التسامح الديني ،

ومعايير فقه الاختلاف في كتاب التزبية

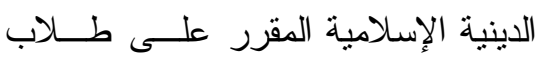

$$
\text { الصف الثاني بالمرحلة الثانوية . }
$$

- تحديد أوجه القوة ، و أوجه الضعف فـي

كتاب التربية الدينية الإسلامية المقــرر ولهدر

على طلاب الــصف التــاني بالمرحلـــة

$$
\text { الثانوية . }
$$

- بناء التصور المقترح لكتـــاب التربيـــة

الدينية الإسلامية المقرر علــى طــلاب

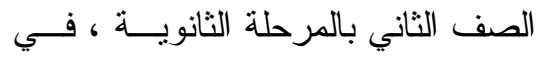

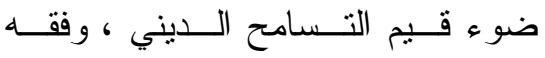

$$
\text { الاختلاف . }
$$

\section{تاسعًا : إجرايات البحث :}

للإجابة عن أسئلة البحث قام الباحث

بالخطوات التالية : - مابه

$$
\text { • للإجابة عن السؤال الأول : }
$$

ما قيم التسامح الديني اللازم تو افرهــــا

في كتاب التربية الدينية الإسلامية المقــررة على طلاب الصف الثاني بالمرحلة الثانوية ؟

$$
\text { قام الباحث بالإجر اعات التالية : }
$$

1- إعداد قائمة أولية بقيم النسامح الديني

اللازم تو افرها فـــي كتــاب التزبيـــة
ب- بطاقة تحليل محتوى كتاب التربية الدينية

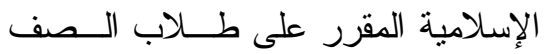

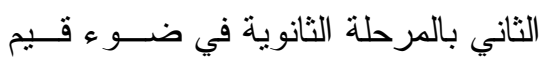

التسامح الديني وفقه الاختلاف.( إعــــاد

$$
\text { (الباحث ) }
$$

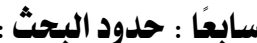

اقتصر البحث الحالي على الحدود التالية :

1- الحدود الموضوعية : كتاب التربيــة

الاينية الإسلامية المقرر على طــلاب

الصف الثاني بالمرحلة الثانوية.

r- الحدود الزماتية : كتاب التربية الدينية

الإسلامية المقرر خلال العام الدراسي

$$
\text { • r.IV/r. } 17
$$

ثامنًا : منهج البحث :

اعتمد البحث الحــالي علــى المــنهج

الوصفي : وهو ذللك المنهج الذي يعتمد على در اسة الو اقع كما هو ، ويهتم بوصفه وصفًا

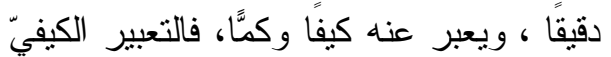

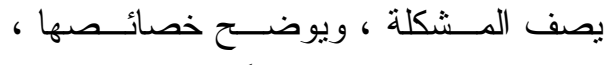
و التعبير الكميّ يعطي وصفا رقميَّا ، ويوضح مقدارها أو حجمها ، ودرجة ارنباطها مسيع العو امل الأخرى المختلفة ، والوصول إلـى استتناجات ، وتعميمها ، وهذا يسهم في فهم

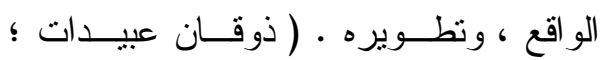

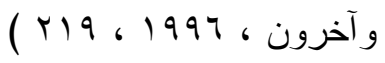


r- التوصل إلى الصورة النهائية لقائمسـة

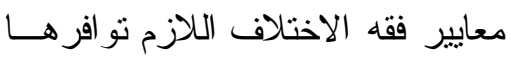
في كتاب التربية الدينيــة الإســـلامية الاحتية

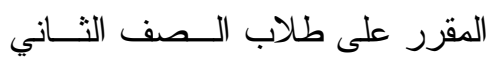

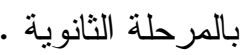

للإجابة عن السؤ الين الثالث والرابع :

ما مدى نو افر قيم التسامح الديني فــي

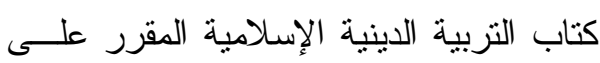

طلاب الصف الثاني بالمرحلة الثانوية ؟ ما مدى توافر معايير فقه الاخــتلاف في كتاب التربية الدينية الإســلامية الدقــرر على طلاب الصف الثاني بالمرحلة الثانوية ؟ قام الباحث بالإجر اعات التالية :

1- بناء صورة أوليــة لبطاقــة تحليـلـ محتوى كتاب التزبية الدينية الإسلامية المقرر على طلاب الـصف الثــاني بالمرحلة الثانوية فــي ضـــو ع قـيم التسامح الديني وفقه الاختلاف . بله r- عرض الصورة الأولية لبطاقة تحليل محتوى كتاب التزبية الدينية الإسلامية

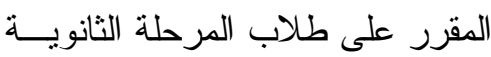
في ضوء قيم التسامح الــديني وفقـــه

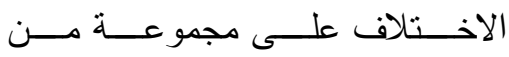
المحكمين؛ لإبداء آر ائهـــ ، وتعـديل الصورة في ضوء ذللك . لمبداء
الدينية الإسلامية المقرر على طــلاب الصف الثاني بالمرحلة الثانوية . r- وضع القائمة الأوليــة فـي صـــورة استبانة، وعرضها على مجموعة من المحكمين ؛ لإبداء آر ائهم ، وتعـديل القائمة في ضوء ذللك . r- التوصل إلى الصورة النهائية لقائمـــة قيم التسامح الديني اللازم تو افرها في كتاب التربية الدينية الإسلامية المقرر على طلاب الصف الثاني بالمرحلـــة الثانوية . ل للإجابة عن السؤال الثاني :

ما معسـيير فقـــه الاخــتلاف الــلازم تو افرها في كتاب التربية الدينية الإســلامية المقرر على طلاب الصف الثناني بالمرحلــــة الإسية

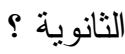
قام الباحث بالإجراءات التالية : 1- إعداد قائهــة أولبـــة بمعـايير فقـــهـ

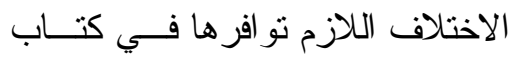
التربية الدينية الإسلامية المقرر على لهى

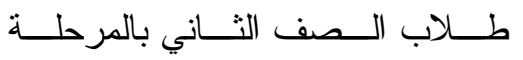
الثانوية. r- وضع القائمة الأوليــة فــي صـورة استبانة، وعرضها على مجموعة من

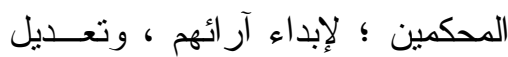
القائمة في ضوء ذللك . 


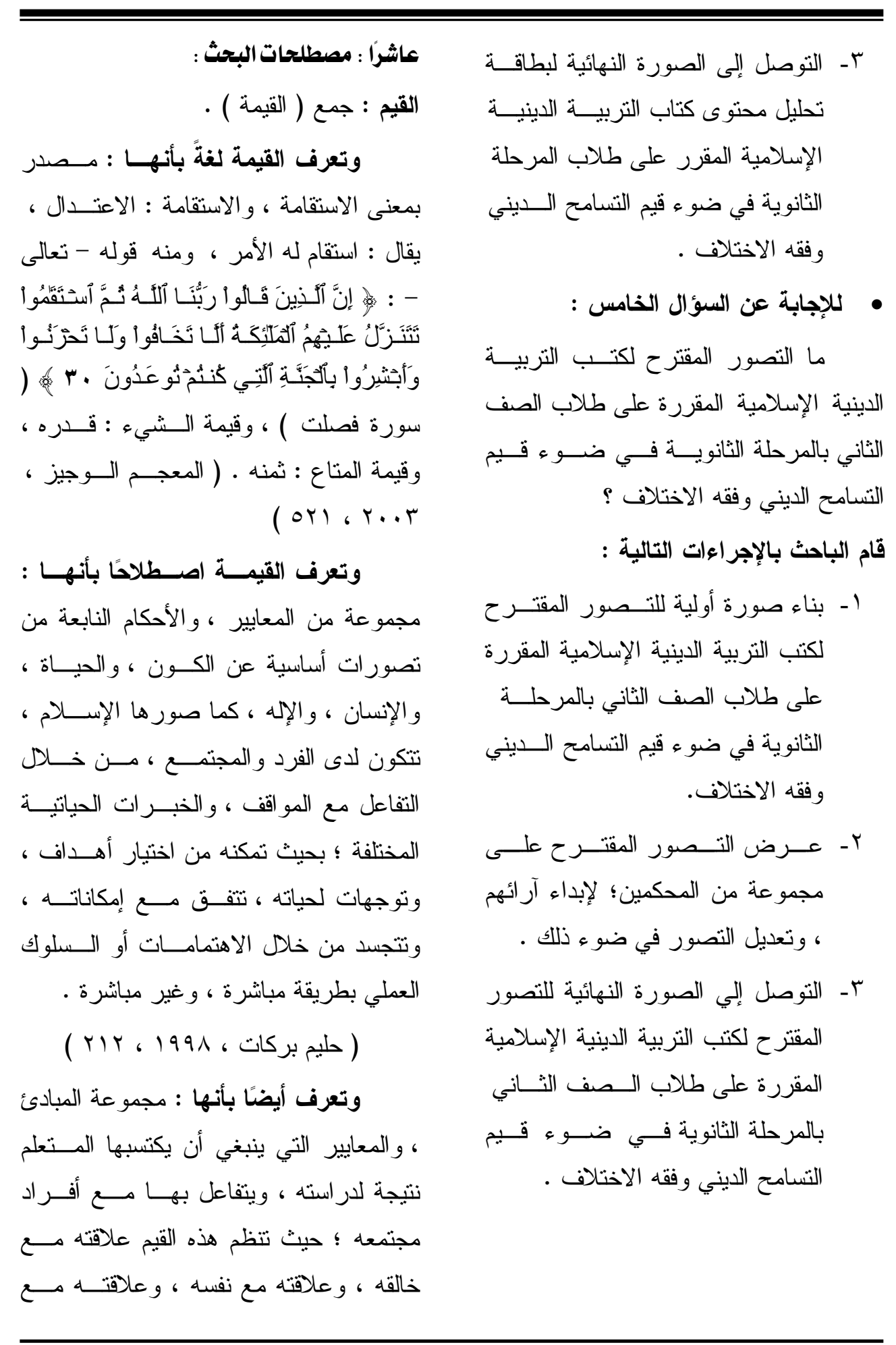




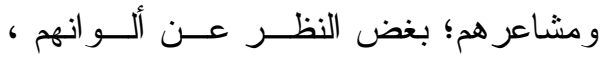
و انتماءاتهم الدينية ، أو العرقية ، أو المذهبية ، أو خلفياتهم الاجتماعية .

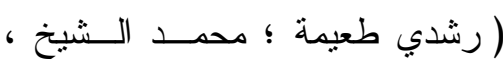

$(19$ ، r...V

ويعرف أيضًا بأنه : العفو عند المقدرة

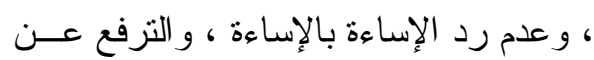

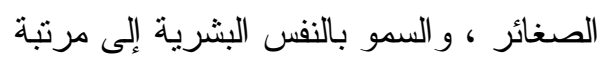

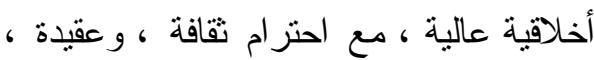

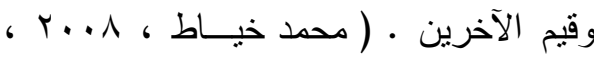

(T)

ويعرف إجرائيّا في هذا البحث بأنه :

السلوك الذي يسلكه طلاب المرحلة الثانوية ؛ تعبيرًا عن تمسكهم بالقيم الدينية ؛ كي ينتشر

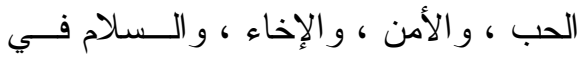
المجتمع - المبت قيم التسامع الايني :

تعرف إجر ائيًا في هذه الدراسة بأنها

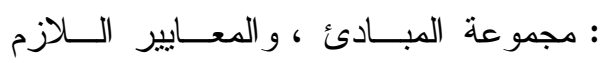

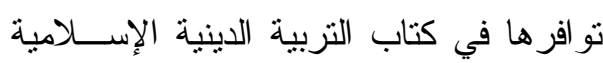
بالمرحلة الثانوية ؛ كي يكتسبها الطلاب مسنـ

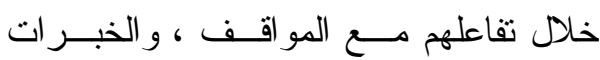
الحياتية المختلفة ؛ حتى يكونو ا قادرين على هلى ولى

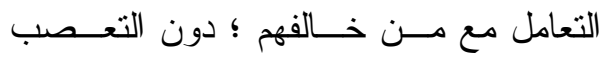
لمذهب أو رأي معين ؛ ليتمكنو ا من التعايش السلمي في المجتمع الذي يتو اجدون فيه ـ

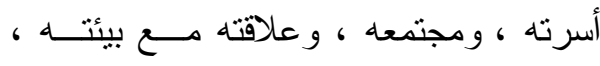

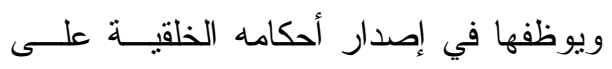

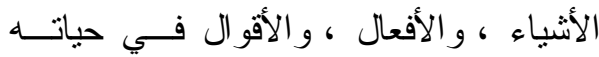

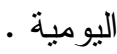

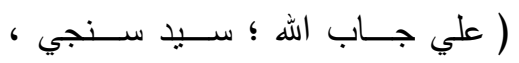

$(9, r \ldots T$

وتعرف القيم إجرائيًا في هذا البحــث

بأنها : مجموعة المبادئ ، و المعايير اللازم تو افرها في كتاب التربية الدينية الإســلامية ولهية بالمرحلة الثانوية في مجالي ( التسامح الديني

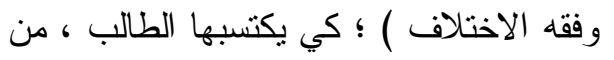

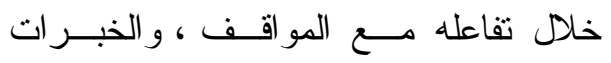

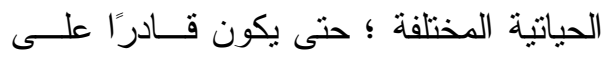
اختيار أهدافه التي تتاسب إمكاناته المتاحة له له

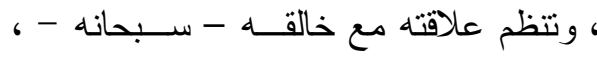
ومع نفسه ، ومع المجتمع الذي يعيش فيه ؛

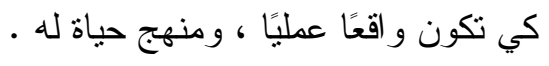

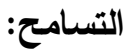
يعرف لغةًً بأنه : مصدر من الفعـلـ

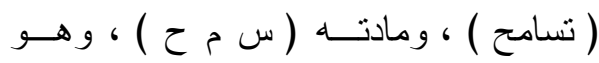

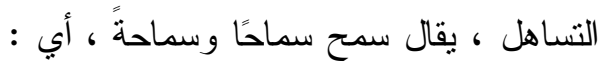
بذل في العسر ، و اليسر ، عن كرم ، وسخاء

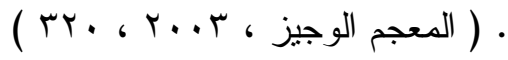
ويعرف التسامـح اصــطلاحًا بأنـــه : قابلية الفرد للتطبيق العملي لمعنى الالتزام ،

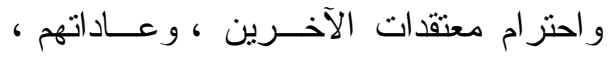


طلاب الصف الثاني بالمرحلـــة الثانويـــة ،

المستمدة من مصادر التشريع الإسلامي بلهردابل

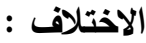

يعرف لغة بأنه : مصدر من الفعـل

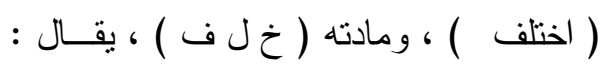

اختلف الثيئان ، أي : لم يتفقا ولم ينساويا .

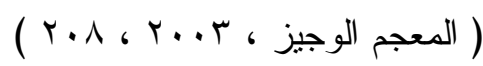

\section{ويعرف الاختلاف اصــلاحًا بأتسـهـه :}

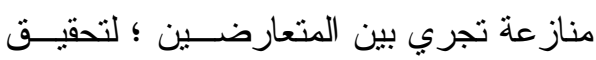

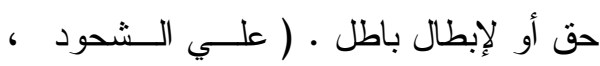

$$
(V) \text {, r... }
$$

يعرف أيضًا بأنه : التباين في الرأي ؛

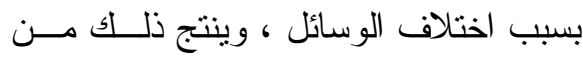

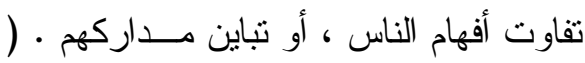

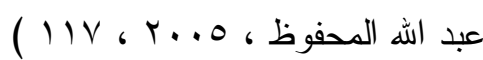
ويعرف إجرائيًا في هذا البحث بأته :

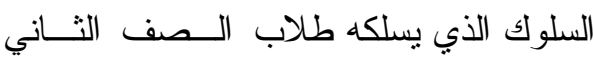
بالمرحلة الثانوية ؛ تعبيرًا عن تمسكهم بالقيم

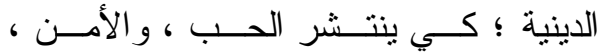

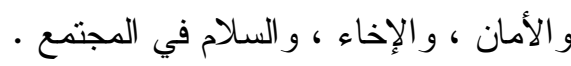

فقه الاختلاف :

يعرف إجر ائيَّا في هذا البحث بأنـــه : مجموعة المبادئ و المعايير التي تتظم العلاقة

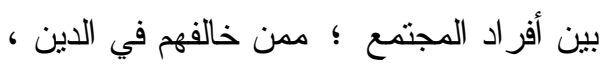

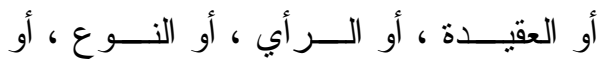

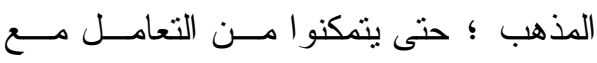

يعرف لغةً بأنه : مصدر من الفعل فقه

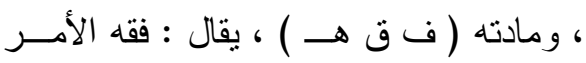

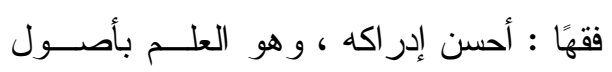

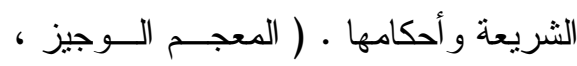

( $\varepsilon \wedge V_{6}, r \ldots r$

\section{ويعرف الفقه اصطلاحًا بأنه : معرفة}

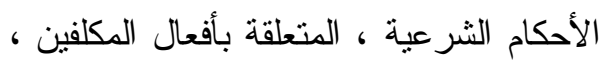

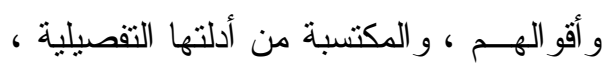

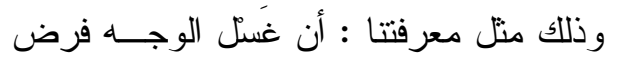

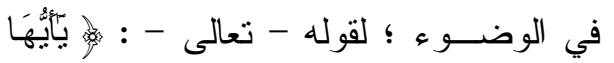

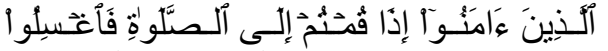

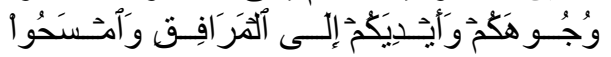

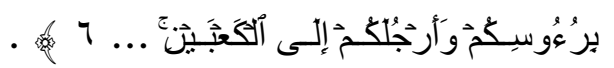

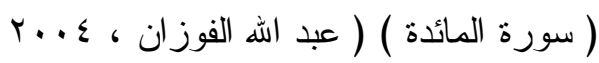

ويعرف أيضًا بأنه : الأحكام الثرعية

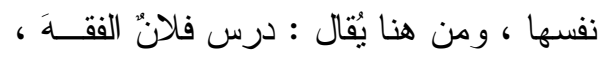

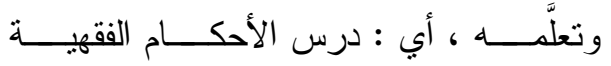
الموجودة في كتب الفقه ، المستمدة من أدلتها لالها التفصيلية ، منل : أحكام الصلاة ، و أحكــام

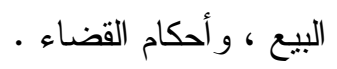

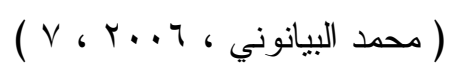

ويعرف إجرائًا في هذا البحث بأنه : معرفة الأحكام الثرعية الموجودة في كتاب

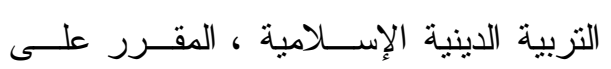




$$
\begin{aligned}
& \text { المقرر على طـــلاب الــصف الثــاني }
\end{aligned}
$$

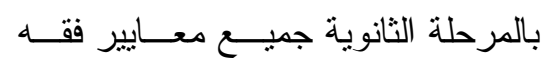

$$
\begin{aligned}
& \text { الاختلاف التي وردت في قائمة معسايير }
\end{aligned}
$$

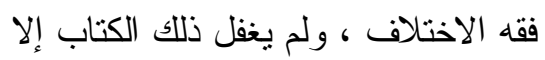

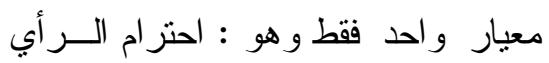

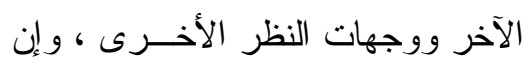

$$
\begin{aligned}
& \text { اختلفت درجة تو افر بـاقي القـيم بــين } \\
& \text { درجة منوسطة وضعيفة. } \\
& \text { ه- يوجد عدم تو ازن في تقديم قيم التـسامح } \\
& \text { الديني في كتاب التزبية الدينية الإسلامية }
\end{aligned}
$$

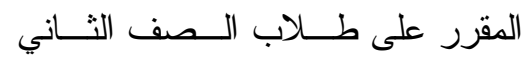

$$
\begin{aligned}
& \text { بالمرحلة الثانوية ؛ إذ تم عرض بعسض }
\end{aligned}
$$

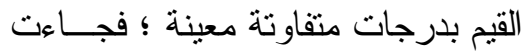

$$
\begin{aligned}
& \text { بدرجة منوسطة مثل : العفو، السماحة، }
\end{aligned}
$$

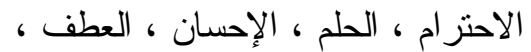

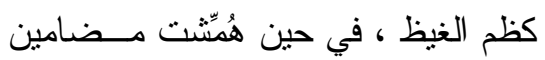

$$
\begin{aligned}
& \text { أخرى، فجاءت بدرجة ضــعيفة مثتـل : }
\end{aligned}
$$

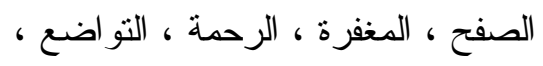

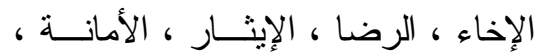

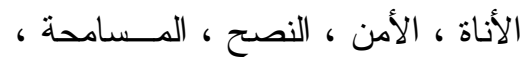

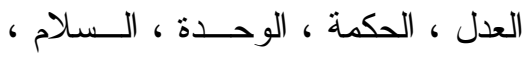

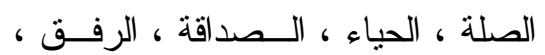

$$
\begin{aligned}
& \text { الصلح ، التغافل . } \\
& \text { 7- يوجد عدم تو ازن في تقــديم قـيم فقـــه } \\
& \text { الاختلاف في كتــاب التربيـــة الدينيـــة فئة }
\end{aligned}
$$

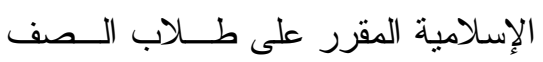

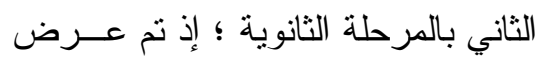

بعضهم على بصيرة ، دون المساس بأصول

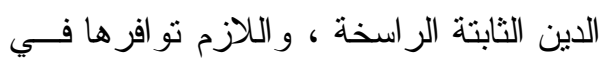

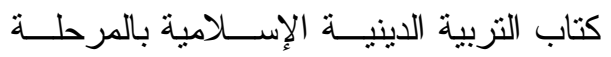
الثانوية ـ الثابة حادي عشر : نتائج البحث: يمكن تلخيص أهم النتائج التي توصلت إليها الار اسة في النقاط التالية: 1 - قائمة بقيم التسامح الديني التــي يجــب تو افرها فـــي كتــاب التربيـــة الدينيــــة

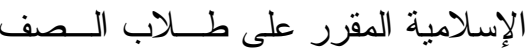

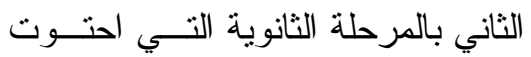

$$
\text { على (اس) قيمة. }
$$

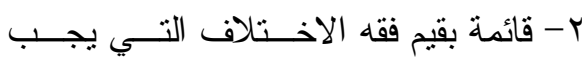

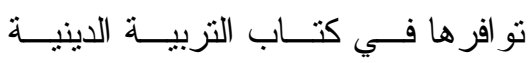

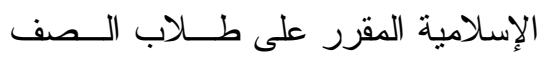

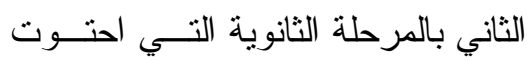

$$
\text { على (· r) قيمة. }
$$

r- تضمين كتاب التزبية الدينية الإســلامية

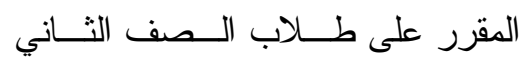
بالمرحلة الثانوية جميع قـيم التـسامح الديني التي وردت في قائمسـة التـسامح الديني ، ولم يغفل ذلك الكتاب إلا قيمتين فقط هما : الهبة ، و التقبل و إن اختلفــت إنـ

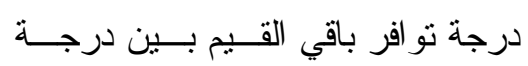
متوسطة وضعيفة. ع- تضمين كتاب التربية الدينية الإســلامية 


$$
\begin{aligned}
& \text { 1- إعداد كتب التزبية الدينية الإســلامية }
\end{aligned}
$$

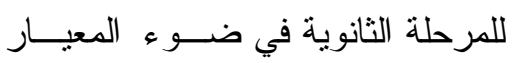

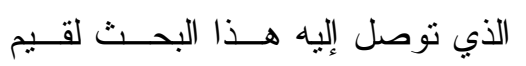

$$
\begin{aligned}
& \text { النسامح الديني وفقه الاختلاف. }
\end{aligned}
$$

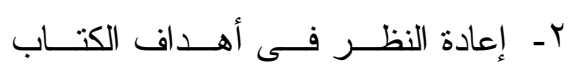

$$
\begin{aligned}
& \text { المدرسى للتزبية الإسلامية ومحتــو اه } \\
& \text { المقرر على طلاب المرحلة الثانوية؛ } \\
& \text { في ضوء ما توصل إليه هذا البحــث }
\end{aligned}
$$

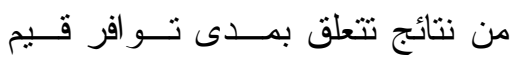

$$
\begin{aligned}
& \text { التسامح الديني وفقه الاختلاف. } \\
& \text { r- استخدام أساليب تقويمية ملائمة لقياس } \\
& \text { السلوك القيمي للتلاميذ - متل استخدام } \\
& \text { بطاقات ملاحظة السلوك القيمي - بدلًا } \\
& \text { من الاكتفاء بأساليب التقويم التقليديــة } \\
& \text { التي تركز على التحصيل المعرفي. } \\
& \text { ع- تطوير محتوى منهج النربية الدينيـــة } \\
& \text { الإسلامية المقرر على طلاب المرحلة } \\
& \text { الثانوية ، في ضوء قيم التسامح الديني } \\
& \text { وفقه الاختلاف. } \\
& \text { 0ـ عرض القيم في كتب التربية الدينيـــة }
\end{aligned}
$$

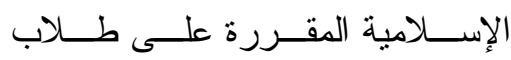

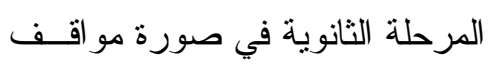

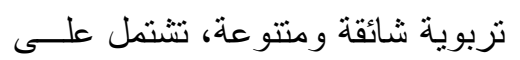

$$
\begin{aligned}
& \text { قيم غير مباشرة. }
\end{aligned}
$$

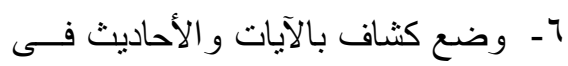

$$
\begin{aligned}
& \text { نهاية الكتاب. }
\end{aligned}
$$

بعض القيم معينة بــدرجات متفاوتــة ؛ فجاءت بدرجة منوسطة منل : تــوقير

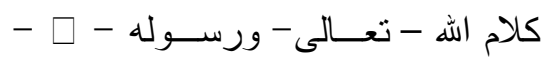
و الرجو ع و الاحتكام إليهــــا، و التـــليم

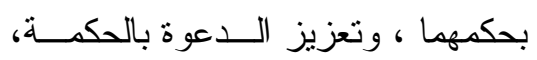

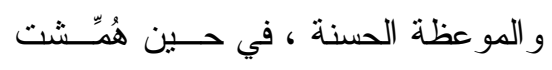
مضامين أخرى، فجاءت بدرجة ضعيفة منل : احتر ام التتوع و الاختلاف، وقبول الآخر ، ونبذ العنف و الكر اهية ، وتحريم

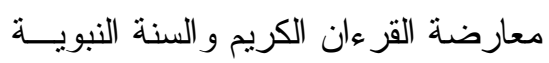

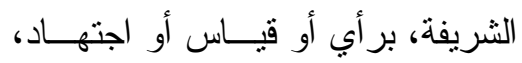

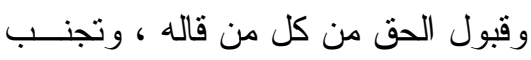

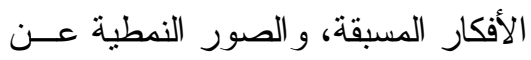

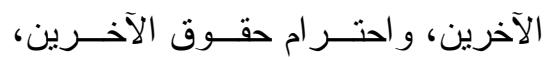

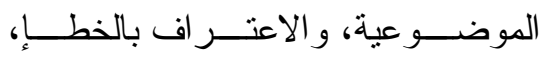
وتجنب التعصب للفكـــة أو الـــر أي، وتجنب التعميم الخطإ، وتقــدير ثقافـــة الآخرين، وتعزيز مقولة: الاختلاف فـي الر أي لا يفسد للود قضية، وغرس آداب الاختلاف المحمود، وتقــير المجتهــــ حتى لو خالف الر أي، وبيان الفرق بــين

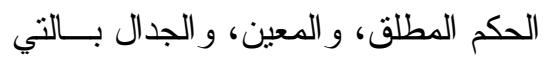
هي أحسن، وتجنب وقوع الاختلاف قدر الإمكان، وتجنب الاختلاف في الأصول.

\section{ثاني عشر : توصيات البحث:}

فى ضوء النتائج التى توصــل إليهــــا البحث، يمكن تقديم التوصيات التالية: 
وتحديات العولمة ، ورقة عمل مقدمــة

لمؤتمر الجامعة الإســلامية العالميــة

بماليزيا.

r. أثرف عمر حجــاج بـربخ (

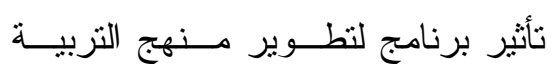

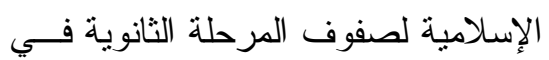

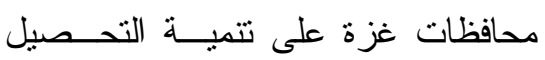

وفهم القضايا المعاصرة، رسالة دكتور اه

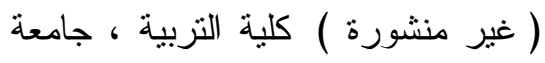

عين شمس.

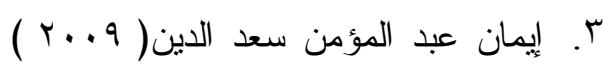

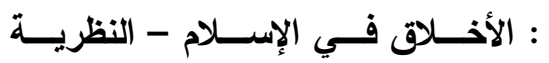

والتطبيق، الرياض: مكتبة الرشد.

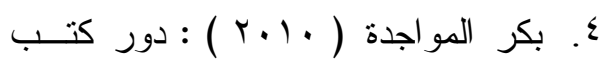

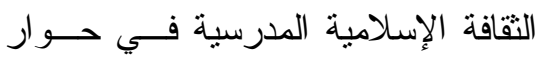

الحضار ات من خلال نشر نقافة الحوار

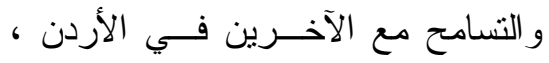

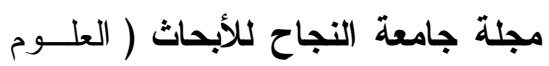

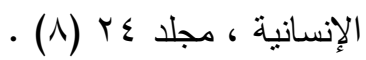

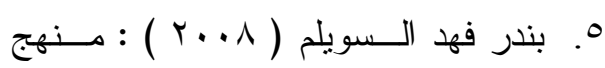

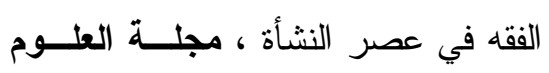

الثرعية ، جامعة الإمام محمد بن سعود

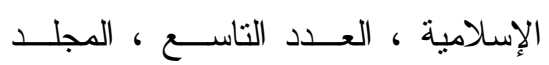

- - إعداد دليل المعلم لتدريس قيم التشامح

$$
\text { الديني وفقه الاختلاف. }
$$

A- ـ عقد دورت تدريبية لمعلمــي التربيـــة

الدينية الإسلامية فـي اســتر اتيجيات

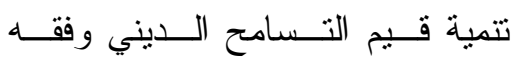

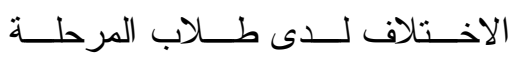

$$
\text { الثانوية. }
$$

ثالث عشر : مقترحات البحث:

ا - تطوير كتب التربية الدينية الإســلامية

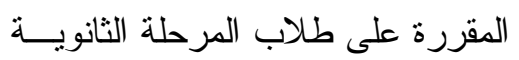

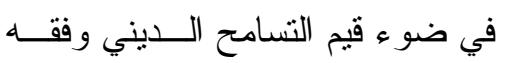

الاختلاف.

Y- ت تقويم محتوى كتب التزبية الإســلامية

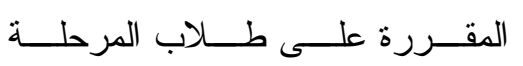

الإعدادية في ضوء قيم التسامح الديني

وفقه الاختلاف.

r- تحليل كتب التربية الإسلامية بالمرحلة

الثانوية في ضوء قيم دينية أخرى.

ع- - بناء وحدات در اسية مصغرة في مادة

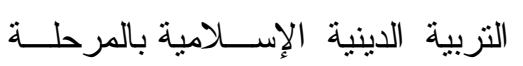

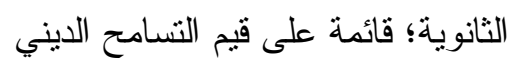

ومعاييرفقه الاختلاف التي تم التوصل فئل فئل

$$
\text { إليها في البحث الحالي. }
$$

المراجع :

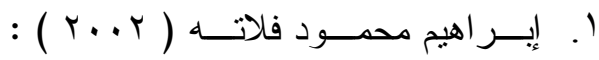

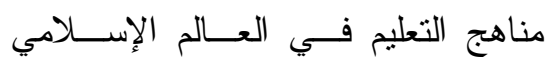




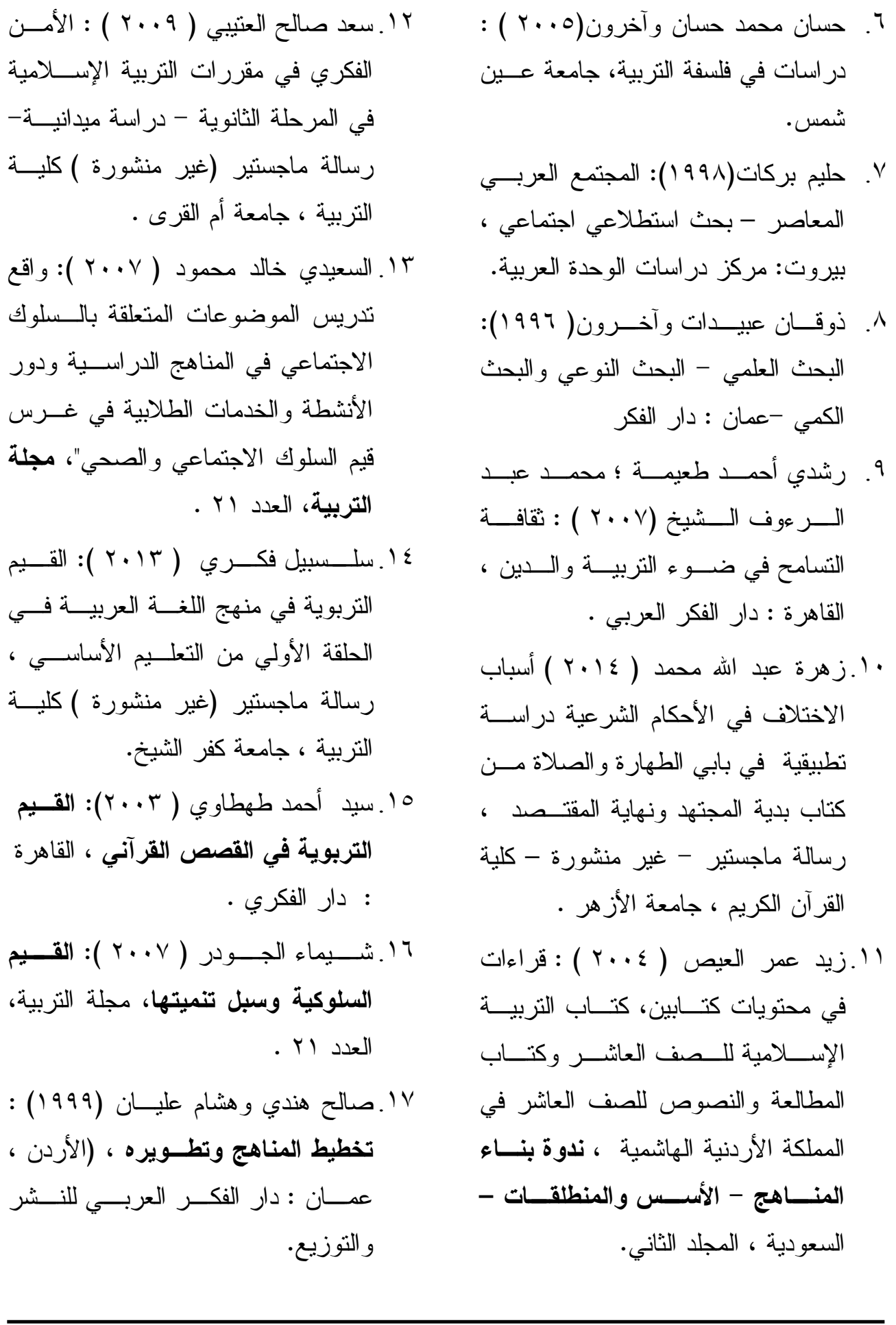


צ Y. علي سعد جاب الله ، سيد محمد الـسيد

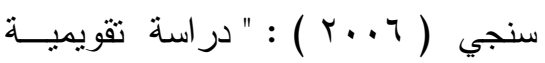

مقارنة بــين مــنهج التزبيــة الدينيــة

الإسـامية ومنهج القيم و الأخــلاق فـي

ضو ء القيم اللازمة لتلاميــذ المرحلـــة

الابتدائية مع مشرو ع لمنهج مقتـرح ح " ،

مجلة البحوث النفسية والتربوية ، كلية

التربية ، جامعة المنوفيــة ، العــدد (ب)

للسنة الحادية و العثرين

OY. علي نايف الشحود( ع . . ب ) : الخلاصة

في بيان أسباب اختلاف الفقهاء ، جدة

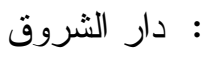

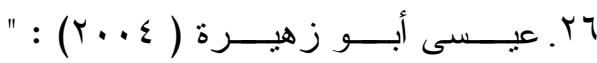

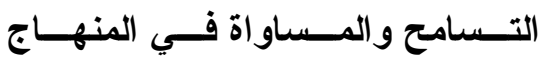

القلسطيني " ، مجلة تشامح ب ، العــدد

ir

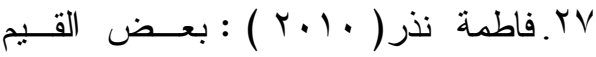

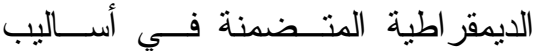

التتشئة الاجتماعية - در اسة مبدانية على

الأسر الكويتية- مجلة كليــة التربيــة

جامعة قطر، العدد 17

אץ. فتحي يــونس وآخـرون ( . . . . ) :

التربية الاينية الإسلامية بين الأصــالة والمعاصرة، القاهرة: عالم الكتب.

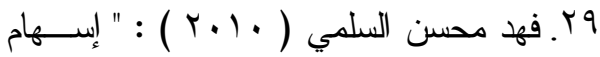

المدرسة في وقاية تلميذ المرحلة الابتدائية
1 1. عامر الخطيب ، ( r . (r) : التربية من

أجل التسامح بين التتظيمات السياسية في المجتمع، غزة : بمركز رشاد الثوا ـ إئ

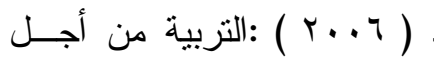
.19

التسامح بين التتظيمات الــسياسية فــي

المجتمع الفلسطيني ، در اســـة نظريــة

قدمت للمؤتمر الثعبي من أجل ثشكيل

حكومة الوحدة الوطنية بمركز رشــاد الثوا ، غزة . الثر

•r. عبد العزيز محمد الغامدي ( q . . . ) : "

العمل الاجتماعي التطوعي مــن منظــور

التزبية الإسـامية وتطبيقاته في المدرســـة

الثانوية ، رسالة ماجستير غير منــشورة ، كلية التربية ، جامعة أم القرى .

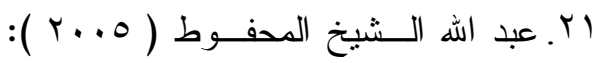
الفقه الإسلامي تعريفه وتطوره ومكانته ، مجلة البحوث الفقهيــة المعاصــرة،

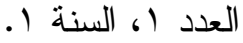

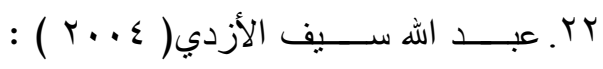

فصول من الأخلاق الإسلامية في ضوء

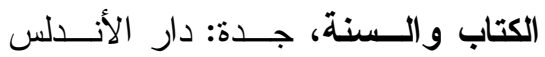

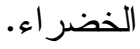

rr. عبد الله صــالح الفــوزان( ع ... ) :

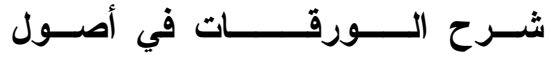

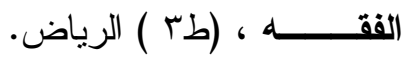


الو اقع المعاصر" ، رسالة دكتـــور اه غيــر

من السلوك العدواني من منظور التزبيـــة

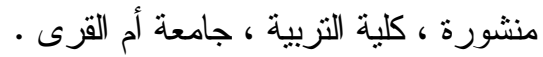

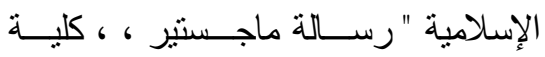

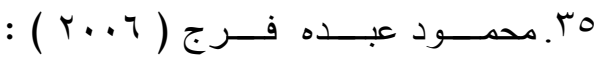

الثزبية ، جامعة أم القري ، السعودية .

المفاهيم الدينية ، القاهرة : عالم الكتاب

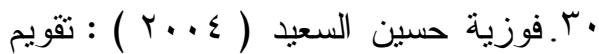

الجديد

طرق تدريس التزبية الدينية الإســلامية

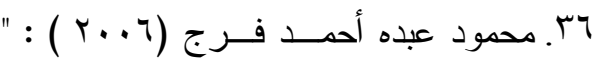

في المرحلة الإعدادية بالتعليم العام فـي لـي

تصور مقترح لتضمين القيم البيائيــة فــي

جمهورية مصر العربيــة فـي ضـــو

مناهج التزبية الإسلامية بمرحلــة التعلــيم

الأهداف المرجوة، دراسة غير منشورة

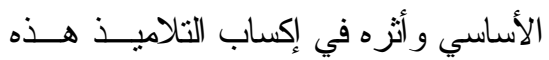

مقدمة لنيل درجة الماجستير في التزبية

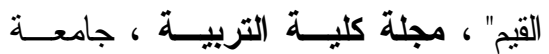
مناهج وطرق تدريس اختصاص طــرق

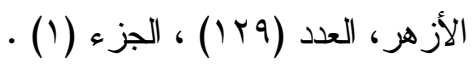

تــدريس التزبيــة الإنـــلامية، جامعــة فئة

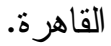

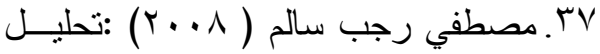

كتاب التربية الدينية الإسلامية بالمرحلة

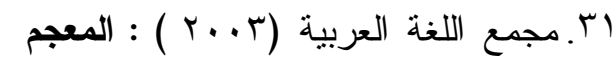

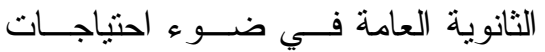

الوجيز ، القاهرة ، الهيئة العامة لشئون

المطابع الأميرية.

الطلاب، مجلة القراعة و المعرفة ، العدد

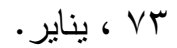

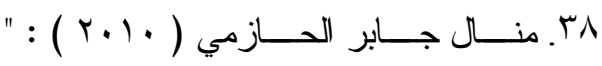

التوجهات التزبوية للتسامح مـن خــد لص

السيرة النبويـــة لابــن هـــام ، رســالة

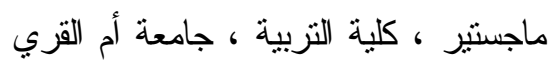

، السعودية .

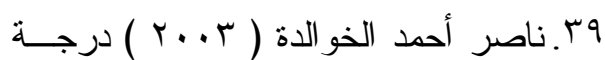

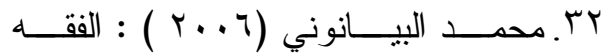

الإسلامي ، مجلة أضـــواء الــشريعة ،

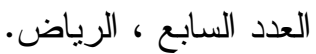

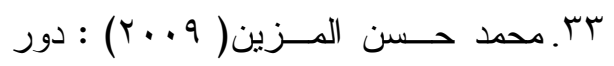

الجامعات الفلسطينية فـــي تعزيـز قـيم

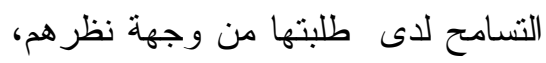

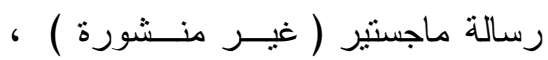

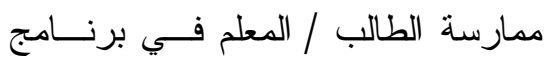

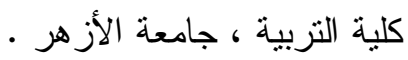

التربية العملية للكفايات التعليمية اللازمة

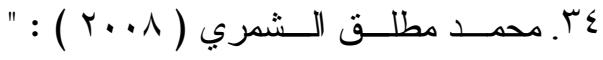

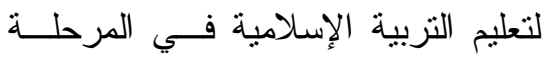

العلاقات الإنسانية مع غير المسلمين فــي

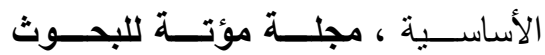

ضوء التزبية الإسلامية وتطبيقاتهــا فـي لإني 
44. Mackinnon , A . \&scarff .seatter , c . ( 1997$)$ constructivism : contradictions and confusion in Teacher Education , In virgina Richardson ( Ed . ) , constructivist Teacher Education : Building New understandings, London The flamer Press .

45. Prawat , R . \& Flodden R. : philosophical perspective on constructivist views of learning , Journal of Educational psychology. Vol .29, 1994.

46. Staver, R . : constructivism : sound theory of Explication the practice of science and science teaching , Journal of Research in science teaching, vol. 35 , No . $10,1998$.
و الدر اسـات، المجلد الثامن عشر ، العــدد

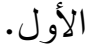

•ـ.ياسين عبد اللطيف عبد الحليم ( ^...

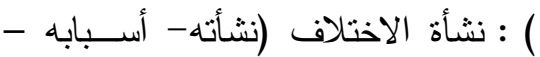

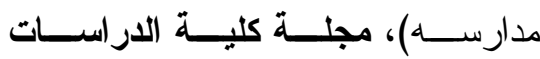

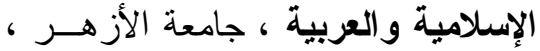
العدد بr ، المجلد الأول.

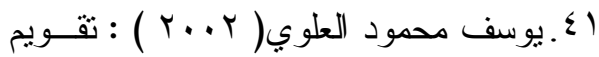

مقرر التزبية الإسلامية للـــف الثالـــث

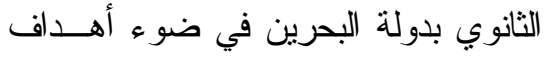

المرحلة ومدي ملاعمته لحـل مـــكلات

الطلاب رسالة ماجستير ، كلية التزبيـــة ،

جامعة طنطا.

42. effectively in educaion" Available at: www.tigr.

Towson. edu. htm.

43. Good, c ., V : Dictionary of Education . N.Y ., MC Graw - Hi 11 Book company, 1973 . 